\title{
صلاح السبد عبد الحى
}

\section{ديدو فرجيليوس .. أصداء ملحمبة وتراجيدية يونانية}

\section{مقدمة البحث:}

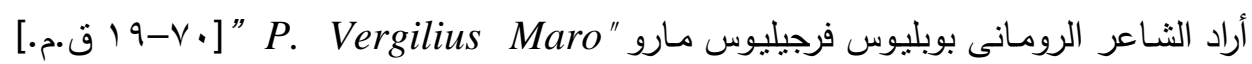

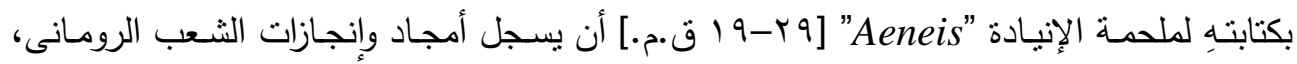

وكيف استوطن هذا الثـعب إقليم لاتيوم "Latium"، وأراد أن يعلى من شـأن الثخصية الرومانيـة

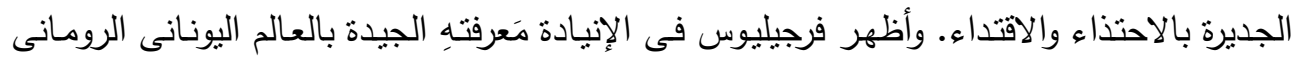

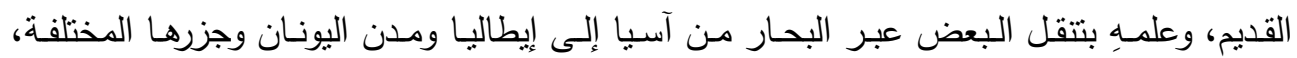

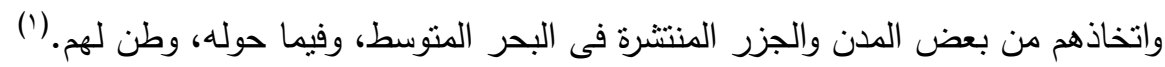

وسـار فرجيليوس فى نسـه لملحمـة الإنيـادة على نهـج الإليـاذة والأوديسية، تلك الملحمتين

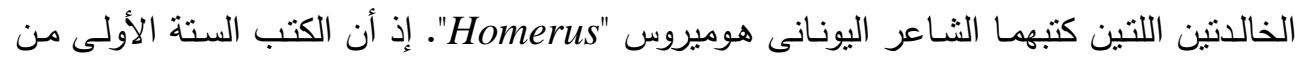

الإنيادة، تمت صياغتها على نهج الأوديسية، حيث التتقل والترحال من مكان إلى آخر حتى يصل

أينياس "Aeneas"، بطل الإنيادة، إلى إقليم لاتيوم فى بدايـة الكتاب السابع. والستة كتب الإنب الأخرى

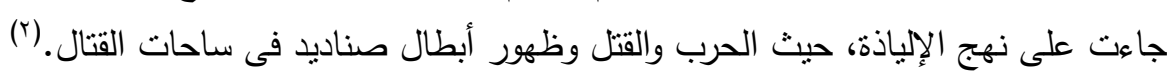

كانت أثتعار هوميروس تتميز بنزعتها الذكورية، فأحداثها تدور حول أبطال ذكور ، ويروى ثلك

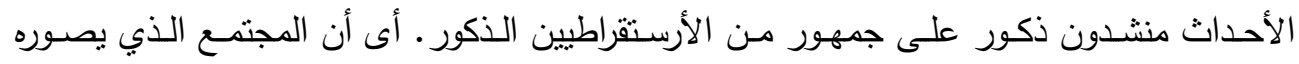

(1) C. R. Beye., Ancient Epic Poetry, Homer, Apollonius and Virgil; Cornel university Press, Ithaca and London, (1993), P. 220.; Cf., H. J. Rose., A Handbook of Latin Literature, From The Earliest Times to The Death of St. Augustine; University Paperbacks, Methuem \& Co LTD: London, (1967), pp. 236, 237, 248.; Cf., J. Higginbotham., Greek and Latin Literature; A comparative Study, London, (1969), pp. 166-167.

(2) K. W. Gransden., Virgil, The Aeneid, N.Y., (1990), p. 29, 113.; Cf., K. Quinn, Virgil's Aeneid, A critical description, Toronto, (1969), pp. 41-46. 


\section{ديدو فرجيليوس .. أصداء ملحمية وتراجيدية يونانية}

هوميروس فى ملحمتيه يُقدر ثقافة الرجل أكثر من ثقافة المرأة، والرجل هو السبد المسيطر فى ذلك

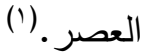

وقد جاء الكُّتاب اليونانيون من بعد هوميروس وساروا على نفس النهج؛ فكان الرجل الذكر هو

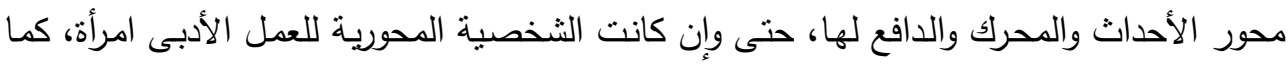
هو الحال فى بعض المسرحيات التراجيدية أو الكوميدية. وورث الأدب اللاتيني عن الأدب اليونانى

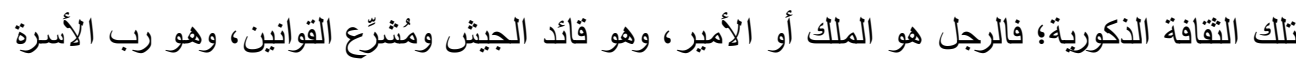

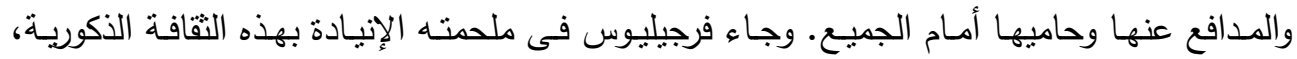

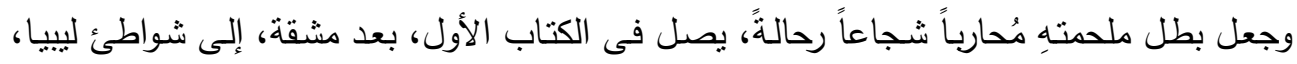
حيث تحكم هنالك امرأة ثُعى ديدو "Dido"، وهى أرملة جميلة قوية شجاعة، كانت قد حطت رحالها

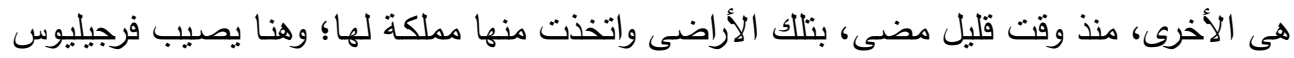
جمهوره بصدمة ومفاجأة غير منوقعة.

إذ وجد القارئ نفسه أمام شخصية نسائية ليست كباقى الثخصيات النسائية، التي كانت ترد من

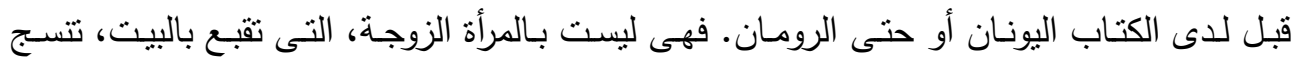

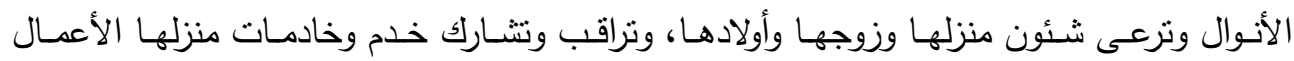

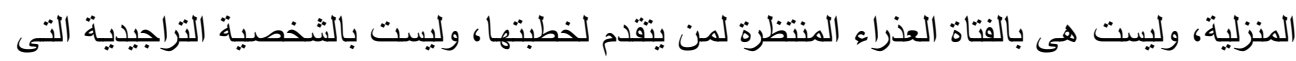

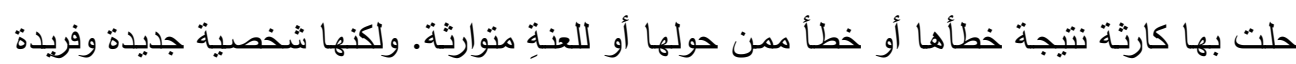
فى تصويرها على القارئ؛ إذ وجد القارئ نفسه أمام امرأة حاكمة، ملكة تحكم شعب وتدئ مهير مملكتها بكفاءة عالية، وتلقََ الاحترام والقبول من الجميع. وهى وحيدة بـلا زوج أو ولد، يحاصرها جيران من

(1) السيد جابر محمد: "جوانب من مشاركة المرأة فى الحروب اليونانية القديمة"، أوراق كلاسيكية. العدد الساد، كلية

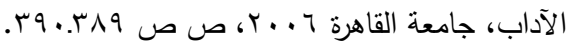

Cf., J. Donaldson., Women: Her Position and Influence in Ancient Greece and Rome and Among Early Christians, press New York, (1973), p. 11.; Cf., C. R. Beye., op. cit., p. 66-67. 


\section{ديدو فرجيليوس .. أصداء ملحمية وتراجيدية يونانية}

الملوك والأمراء الرجال، الذين كان البعض منهم يرغبها زوجة له. (') وهى أرملة وفية لذكرى زوجها،

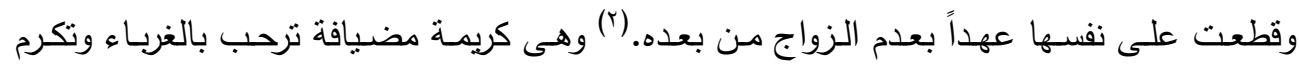

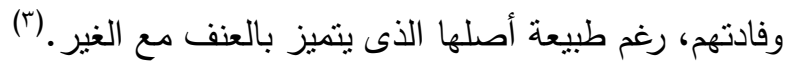

وتظل شخصية ديدو "Dido" فى تطور وتتامى لدى القارئ؛ حتى يتعرف على جميع خصالها

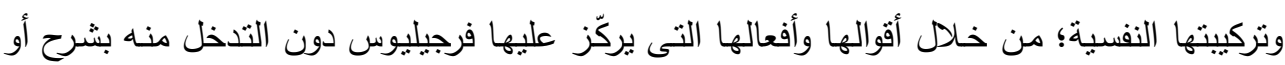
بوصف للثخصية ذاتها. ويُعد فرجيليوس مفاجأة لجمهوره عندما نقابل تلك الملكة بطل الإنيادة أينياس، الذى وصل إلى مملكتها وهو بـلا وطن الآن، فتتحرك عاطفتها ناحيته ويملئ حبـه قلبها ويسيطر عليها؛ ومن ثم تتبرأ هى من قسمها الذى قطعته على نفسها بعدم الزواج بعد موت زوجها. ورغم ما قدمته من عروض على أينياس حتى يُقيم ويبقىَ إلى جوارها في مملكتها قرطاجة، إلا أنه

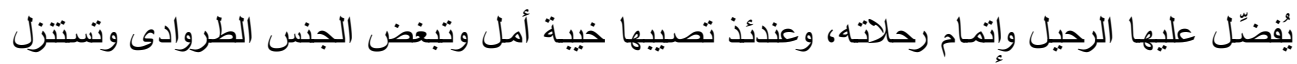

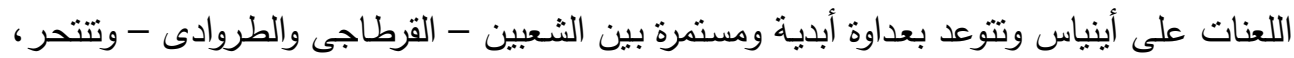

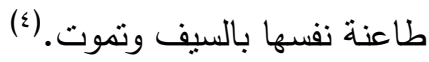

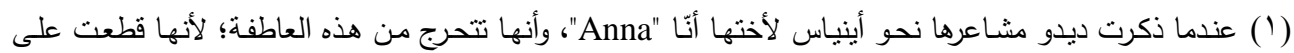

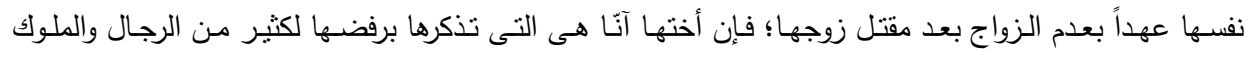

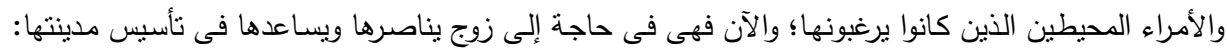

Cf., Verg. Aen., IV. 31-44.

(2) Verg. Aen., IV. 15-19.

(r) يذكر فرجيليوس أن الملكة ديدو من أصول فينيقية، وأن الفينيقيون يتميزون بالعنف مع الآخرين. Cf., Verg. Aen., I, 302-303. cf., C. R. Beye, op. cit., p. 233.

(§) تكتمل صورة شخصية ديدو فى الكتاب الرابع، ذلك الكتاب الذى يتوارى فيه البطل أينياس ويترك المجال للملكة

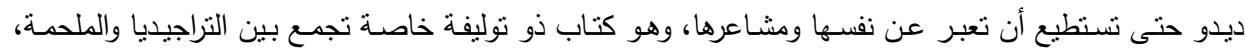

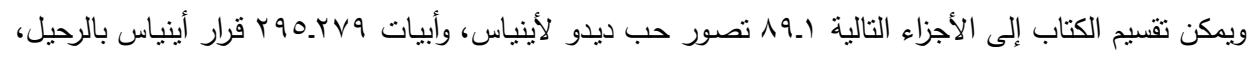

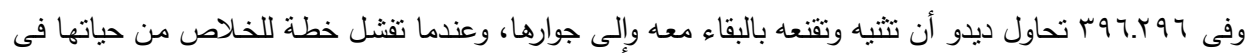

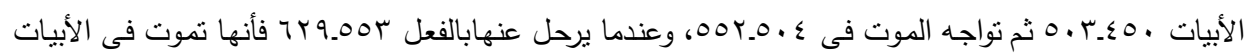




\section{ديدو فرجيليوس .. أصداء ملحمية وتراجيدية يونانية}

فهذه هـى ديدو التى قدمها فرجيليوس بالكتابين الأول والرابـ فى الإنيادة، والتي أصساب بها

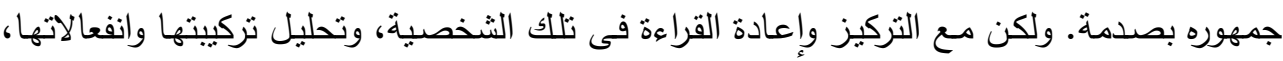
نجد أنها عبارة عن أصداء لشخصيات أدبية يونانية مختلفة، وخليط من شخصيات ذكورية ونسائية عديدة. استطاع فرجيليوس من خلالها أن يظهر قدرته على الخلق والإبداع والاستفادة من قراءاته،

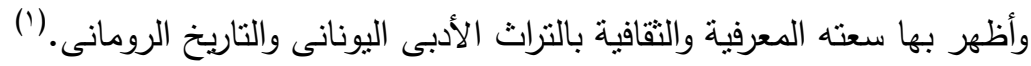

إذ تجمع شخصية ديدو بين كل من أخيلليوس "Achilleus" وأيـاكس "Aiax" أبطسال ملحمـة

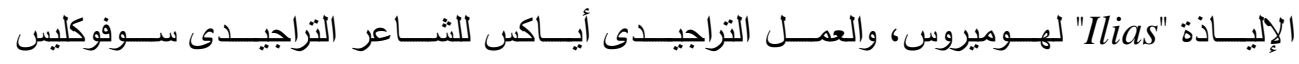
"Sophocles" الفايـاكيين "Phaeaces" بملحمـة الأوديسية "Odysseia" لهوميروس، والتى بـادرت بتقديم العون

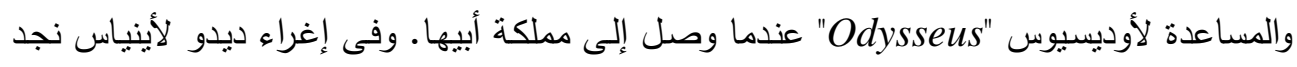

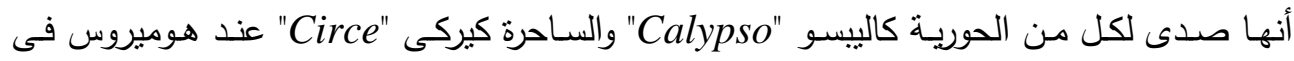

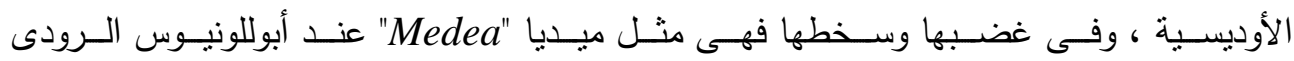

Cf., K. Quinn, op. cit., P. 51, 135 - 137.; cf., C. R. Beye, op. cit., P. 233.

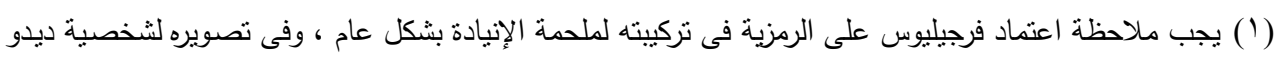

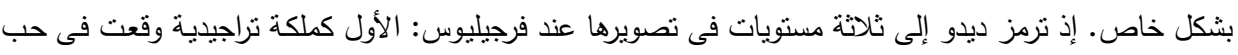

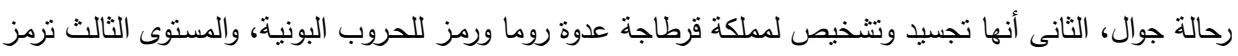

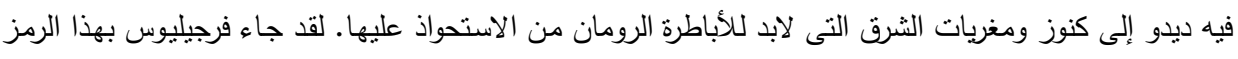

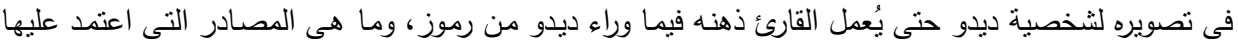

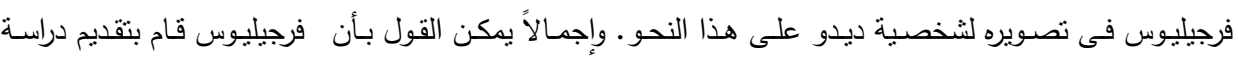
موضوعية ومتعقة لتلاك المرأة الملكة المحبة المهجورة المنتحرة ديدو.

Cf., K. Quinn, op. cit., p. 55, 111.

وقد أظهر فرجيليوس مدى إطلاعه ومعرفته بالتراث الأدبى اليونانى عندما أورد فشل ديدو فى كسب ود أينياس،

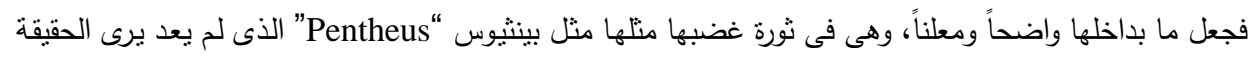

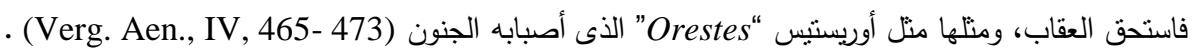

Cf., R. A. Hornsby, “The Vergilian Simile as Means of Judgment”, C. J., vol. 60, 1965, p. 341. 


\section{ديدو فرجيليوس .. أصداء ملحمية وتراجيدية يونانية}

"Apollonius Rhodius" سوفوكليس. حتى وهى غاضبة فى العالم الآخر فى الكتاب السادس نجدها صديً لغضب أياكس

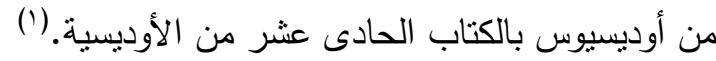

وإلى جانـب أنهـا صـدى لشخصـيات أدبيـة يونانيـة، تراجيديـة وملحميـة، فهى أيضـاً صـدى

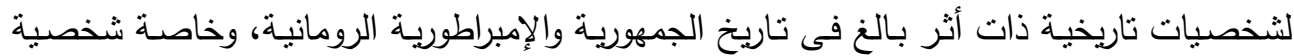
ملكة مصر كليوباترة "Cleopatra".

وعلى ذلك فسوف يتعرض البحث بالدراسة لهذه الأصداء تبعاً لتتامي شخصية ديدو كما أوردها فرجيليوس فى الإنيادة وكما تتفق مع فكرة وهدف البحث؛ حيث مكانة الفرد داخل الدولة، وماذا يجب

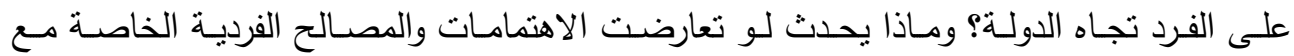
الاهنمامات والمصالح القومية العامة؟ ا ـ ديدو المساعدة المحبة الرومانسية: فى الكتاب الأول من ملحمـة الإنيادة، أظهر فرجيليوس الملكة ديدو كثخصية كريمة مضيافة

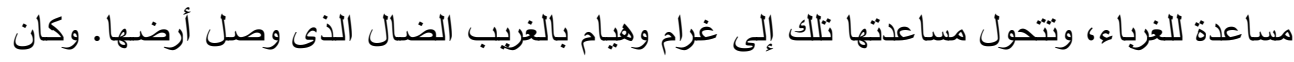

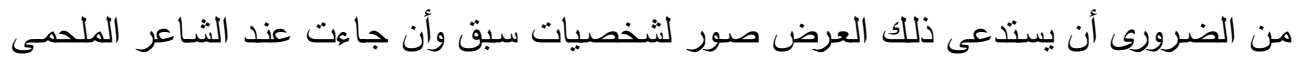
اليونانى هوميروس، وكذللك عند الثشاعر الملحمى السكندرى أبولللنيوس الرودى.

فقد ذكر هوميروس فى الأوديسية أن أوديسيوس عندما تحطم طوفه فقد أخذ يسبح فى البحر حتى وصل وحيداً إلى أرض الفاياكيين، حيث يحكم الملك ألكينوس "Alcinous"، والذي كانت لله

(1) K. Quinn., op. cit., p. 278-282.

يرغب فرجيليوس بتصويره لثخصية ديدو بإعادة عرض ميديا يوريبيديس وميديا أبوللونيوس. إذ تنثل ميديا

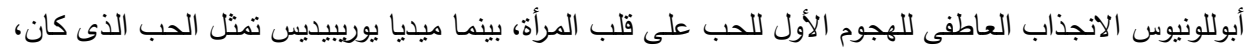

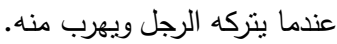




\section{ديدو فرجيليوس .. أصداء ملحمية وتراجيدية يونانية}

ابنـة تـدعى ناوسـيكا، شـابة جميلـة عنيـدة تضـارع الربـة أرتمـيس فـى جمالهـا،(') وعندما تحـدث

$$
\text { أوديسيوس إليها فأنه يصفها بقوله لها: }
$$

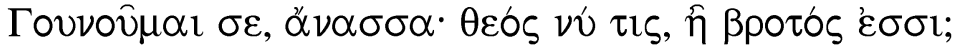

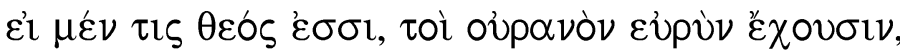

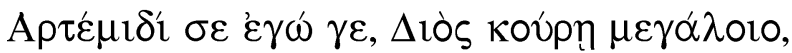

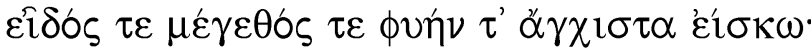

(Hom. Od., VI, 149-152) $)^{(2)}$

$$
\begin{aligned}
& \text { "يا أيتها الملكة. أننى أنتسل إليك، إنك إله ما أم أحد البشر الآن؟ فلو }
\end{aligned}
$$

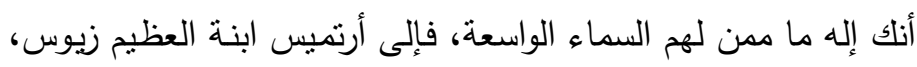

$$
\begin{aligned}
& \text { إذ أننى أرى أنك الأكثر شبهاً لها فيالعظمة والقوام". }
\end{aligned}
$$

وفور سماعها لمديحه وتتبيهه لها بالربـة أرتميس، فأن ناوسيكا تبادر بتقديم المساعدة للذلك

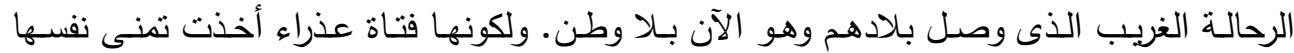
بالزواج منه، خاصة بعد أن أغتسل أوديسيوس فى ماء النهر وبدت عليه علامات الإمارة والجمال؛

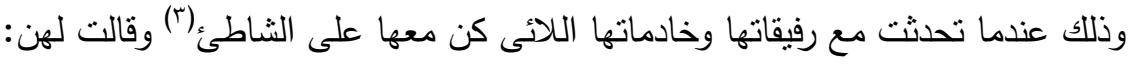

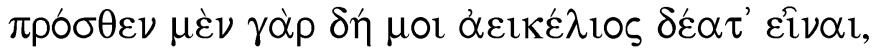

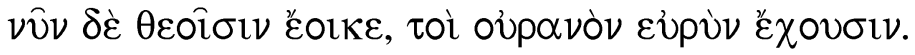

(1) عندما يتحطم طوف أوديسيوس أمام شواطئ سخيريا، ويستطيع بعد جها أن يخرج من البحر ، ويجد مكاناًً أمناً ينام

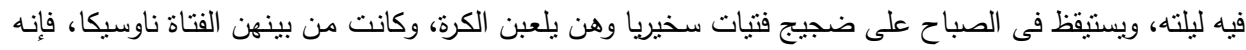

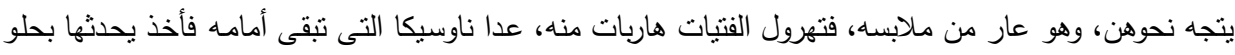
الكلام لكسب ودها كى تساعده.

Cf., J. J. Clauss and S. I. Johnstow, Medea, Essays on Medea in Myth, Literature, Philosophy and Art, edd. Princetm University Press, (1997), p. 165.; Cf. C. R. Beye., op. cit., p. 233.; Cf., J. Higginbotham, op. cit., P. 180.

(r) لقد سبق وقارن هوميروس بنفسه بين الفناة ناوسيكا والربة أرتميس ورفاقها وهن يلعبن على تلال الجبال مع الظباء

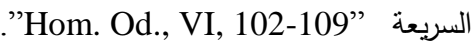

(3) J. J. Clauss and S. I. Johnstow., op. cit., pp. 168-179. 


\section{ديدو فرجيليوس .. أصداء ملحمية وتراجيدية يونانية}

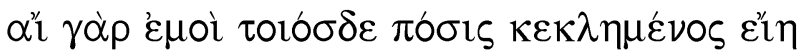

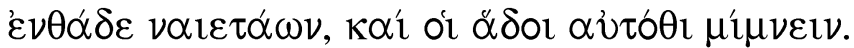

(Hom. Od., VI, 242-245)

"لأنـه بدا أمسامى جدير بالثفقة، أمسا الآن فأنه بشبه الآلهة، هؤلاء

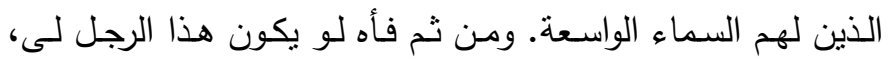

ويطلق عليه زوج، ويسكن هنا، إذ أنه لنىء جميل أن يقيم هنا".

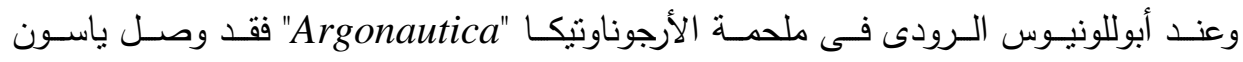

"Iason"

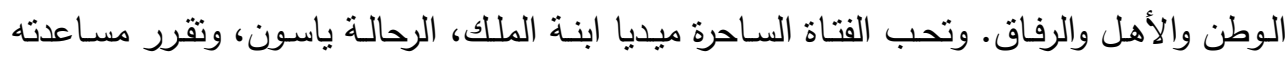
ومساندته، ومن ثم فأنها تذهب لمقابلته فى معبد الربـة هيكاتى "Hecate"، وكانت وهى وهى فى طريقها

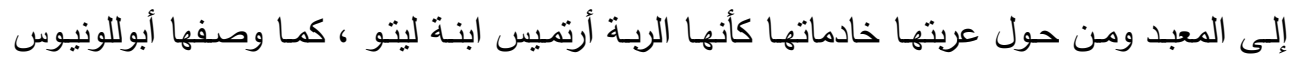

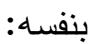

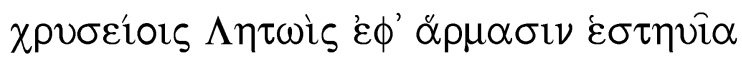

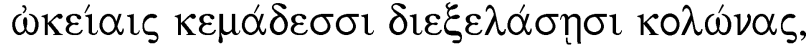

(Apol. Arg., III, 878 - 879 )

$$
\text { "كابنـة ليتو وهى واقفة على عربتها الذهبية وتقود الظباء الصـيرة }
$$

وعندما أراد فرجيليوس أن بصوّر حالة الملكة ديدو، التى وصل إلى أرض مملكتها غريب ضال بلا وطن أو رفيق، فلقد اعتمد على ما لديه من مخزون ثقافى يونانى.

فقد ذكر فرجيليوس أنه عندما كان أينياس ملفوفاً فى سحابة تخفيه عن الأنظار وهو داخل معبد الربة جونو "Juno" بمدينة قرطاجة، فقد وصلت الملكة ديدو إلى المعبد ومعها رفيقاتها، يحطن بها

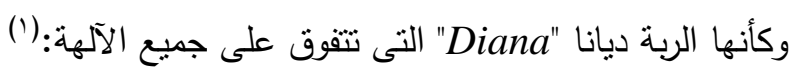
regina ad templum, forma pulcherrima Dido,

(1) K.Quinn., op. cit., p. 57, 434.; cf., R. A. Hornsby., op. cit., p. 338 . 


\section{ديدو فرجيليوس .. أصداء ملحمية وتراجيدية يونانية}

incessit magna iuuenum stipante caterua. qualis in Eurotae ripis aut per iuga Cynthi exercet Diana choros, quam mille secutae hinc atque hinc glomerantur Oreades;

(Verg. Aen., I, 496-500)

"توجهت الملكة إلى المعبد، ديدو ذات الثكل الجميل جداً؛ محاطة

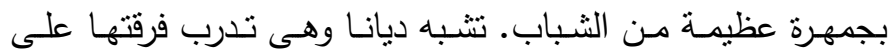

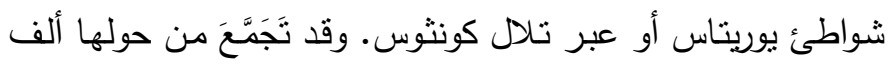

$$
\text { تابعة أوريادية هنا وهناك". }
$$

وتُبادر الملكة ديدو بتقديم المساعدة لأينياس ورفاقه قبل أن تراه؛ إذ أنها نقابلت مع بعض من

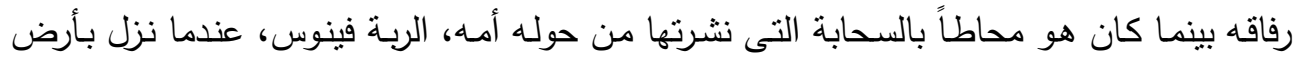

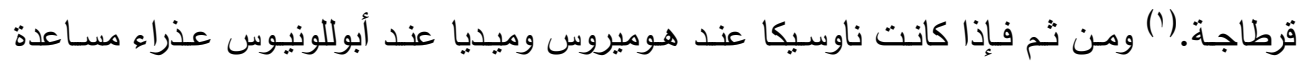
"Helper maiden" شُبُت بالربة أرتميس ـ ديانا ـ ابنة ليتو. فئر

ويتقدم فرجيليوس فى تصويره لشخصية ديدو إلى الأمسام خطوة أخرى، وذلك عندما تطورت مساعدتها للغريب الضـال إلى علاقة عاطفية. إذ طوّرَ فرجيليوس لقاء ديدو مع أينياس من مجرد تقديم المساعدة إلى هيام وغرام ومحبة ورغبة فى الاستحواذ والإبقاء على الغريب إلى الجوار وعدم

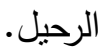

(1) (1) تُظهر ديدو مدى كرمها بإعداد وليمة فاخرة لأينياس ورفاقه

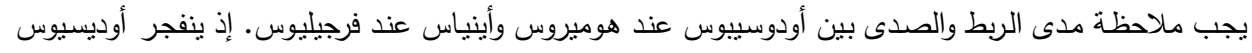

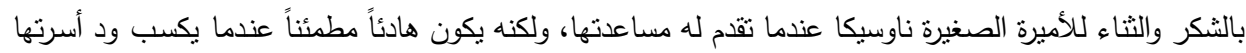

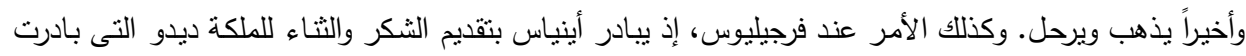

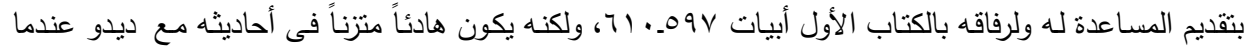

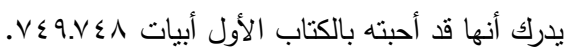

Cf., K. Quinn., op. cit., pp. 103-104, 108. 


\section{ديدو فرجيليوس .. أصداء ملحمية وتراجيدية يونانية}

وقد جاء فى التراث اليونانى ـ من قبل ـ الكثير من صور الرغبة فى الإبقاء على الغريب، الذى الذى

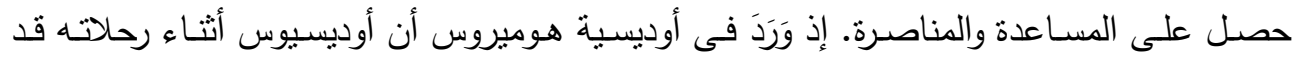

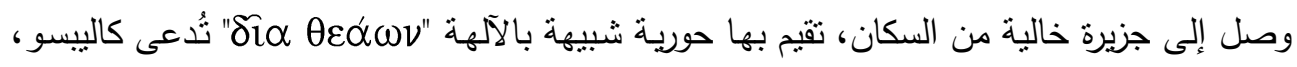

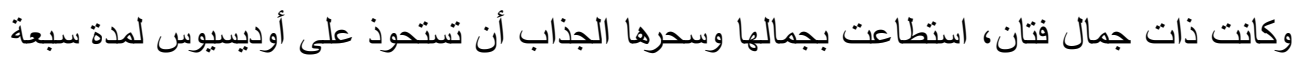

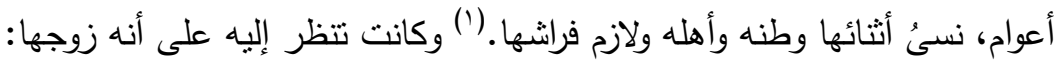

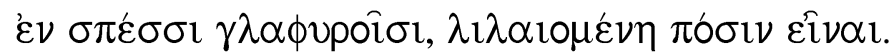

(Hom. Od., I, 15)

\section{"فى كهوفها الفارغة، راغبة فى أن يكون زوجها"}

وورد فـى الأوديسـية أيضـاً، أن أوديسـيوس وصـل إلى جزيـرة آيايـا "Aeaea"؛ والتى نسـنها

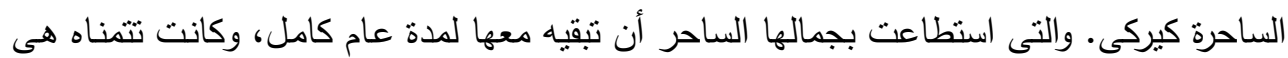

$$
\text { الأخرى زوجاً لها مثل الحورية كاليبسو : }
$$

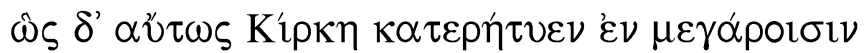

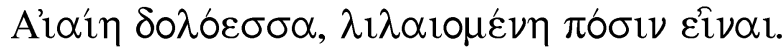

(Hom. Od., IX, 31-32)

$$
\text { "وكذلك أعاقتتى كيركى المخادعة فى قصرها فى أيايا، راغبة فى }
$$

إن كل من كاليبسو وكيركى كانتا ترفضان رحيل أوديسيوس عنهما وكانتا تبغيان إقامته، لولا أن رحيله جاء بناء على رغبة وأمر إلهى. ولقد كانت هذه الصورة فى مخيلة وثقافة فرجيليوس، ومن ثن إنمان

(1) W. S. Anderson, "Calypso and Elysium”, C.J., vol. 54, (1958), p. 8.; cf., M. J. Edwards., "Scenes From The Later Wanderings of Odysseus", C.Q., vol., 38 II, (1988), p. 510 . 


\section{ديدو فرجيليوس .. أصداء ملحمية وتراجيدية يونانية}

كان لها صداها عندما صََّّرَ الملكة ديدو . فكل من الثـاعرين هوميروس وفرجيليوس جعل لدى ألى

المرأة أو العذراء المساعدة رغبة فى الاستحواذ على من ساعدته والعمل على عدم رحيله عنها.(')

إن الثخصيات النسائية المساعدة عند هوميروس تقوم بتقديم المساعدة قبل أن ترتبط بعاطفة مع إع

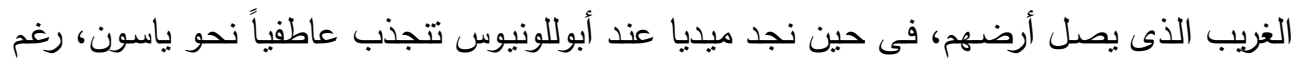

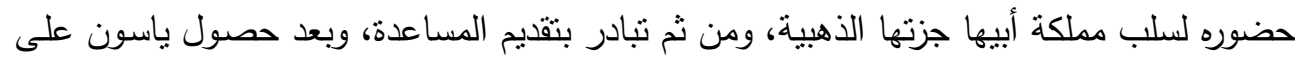

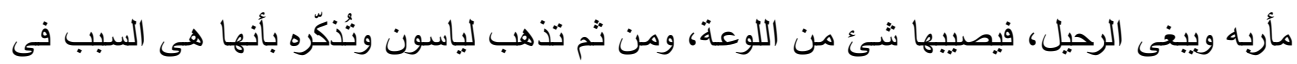

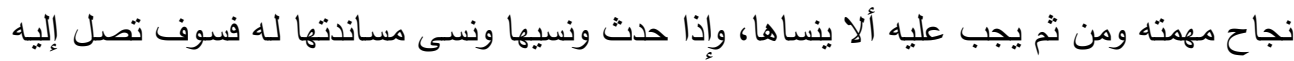

فى وطنه وتتنقم منه:

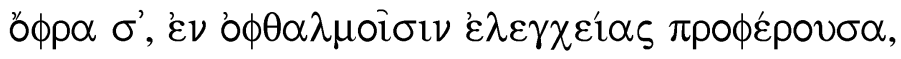

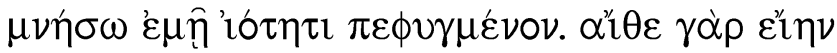

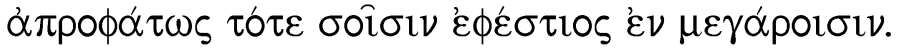

(Apol. Arg., III, 1115-1117)

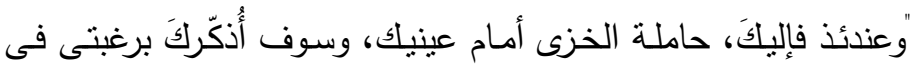

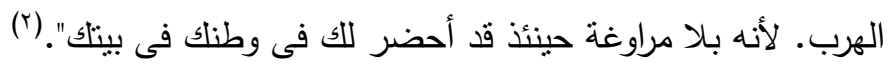

(1) أخذت الحورية كالوبسو تحاور أوديسيوس قبل رحيله وتتاقثه بأسلوب منطقى؛ لعله بمكث معها ويقلع عن فكرة

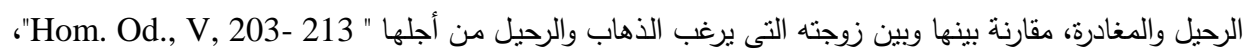

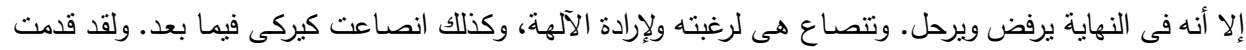

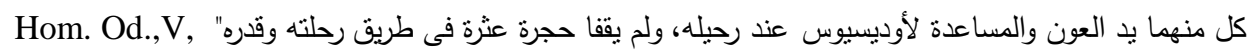

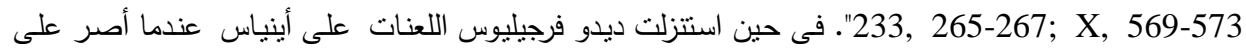

$$
\text { الرحيل والمغادرة تلبية لقدره ولأوامر الآلهة . }
$$

E. B. Holtsmark., "Spiritual Rebirth of the Hero: Odyssey 5", C. J., vol. 61, (1966), p.

207, 209; cf., R. B. Rutherford., "The Philosophy of the Odyssey", J.H.S., vol. 106,

(1986), p. 151-154.; cf., W. S. Anderson., op. cit., p. 9.

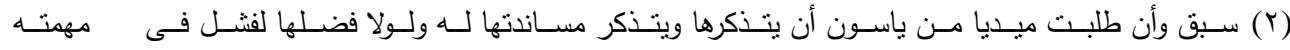

."Apol. Arg., III, 1069-1071" 


\section{ديدو فرجيليوس .. أصداء ملحمية وتراجيدية يونانية}

ولقد كان لثخصية ميديا أبوللونيوس صدى وأثز واسع على تصوير فرجيليوس لثخصية الملكة

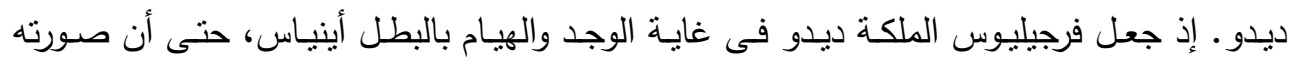

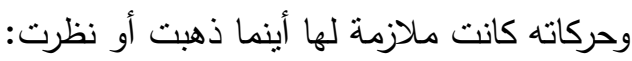

multa viri virtus animo multusque recursat gentis honos; haerent infixi pectore voltus verbaque, nec placidam membris dat cura quietem.

(Verg. Aen., IV, 3-5)

"كانت ـ الملكة . تسترجع بذهنها الرجولة الطاغية للرجل واحترامه البالغ

لعشيرته، وظلت نظراته القوية وكلماته عالقة بقلبها.

$$
\text { ولم يعطى الحب الراحة أو الهدوء لأعضائها". }
$$

ونتيجة هذا الوجد والهيام "infandus amor" الذى تعيشه ديدو مع أينياس فقد انصرفت عن أمور وشئون مملكتها التى توقفت تماماً الآن "Verg. Aen., IV, 86-89"، وكان جُجل اهتمامها

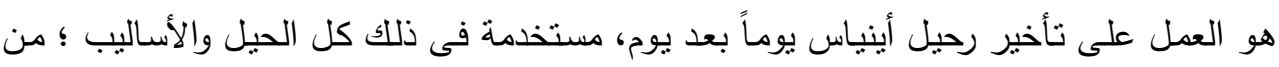

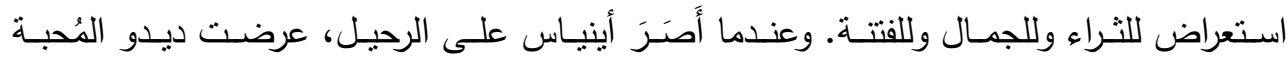
"amans"

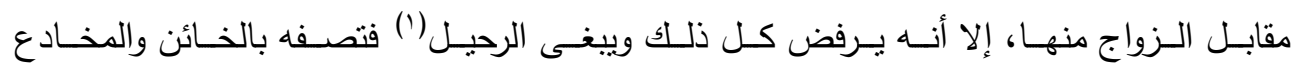
"perfidus, dissimulans"

ثم تعود ميديا وتذكّره بأنها سوف تتنقم منه إذا نسى فضلها ومساندتها له "Apol. Arg., III, 1105-1117".

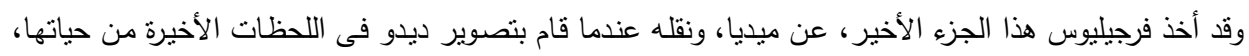

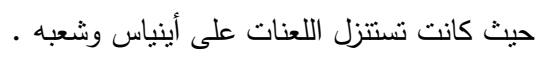

Cf., J. J. Clauss, "Domestici Hostes: The Nausicaa in Medea, The Cataline in Hannibal", Materiali e Discussioni per L' Analisi dei testi Classici, (1997), Piza, Rom. pp. 167-168.

(1) C. R. Beye, Op. Cit., P. 233.

يجب ملاحظة المغزى من إظهار الثراء أمام البطل الجوال القادم إلى أرضها، إذ أن هذا المشهد لدى فرجيليوس

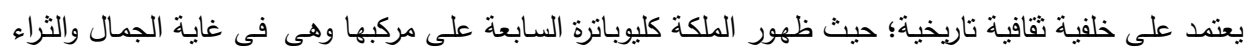




\section{ديدو فرجيليوس .. أصداء ملحمية وتراجيدية يونانية}

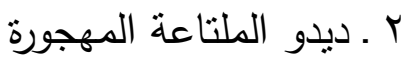

كان من الطبيعى على ملكة قد أقسمت بعدم الزواج بعد موت زوجها أن تشعر بالمهانة واللوعة

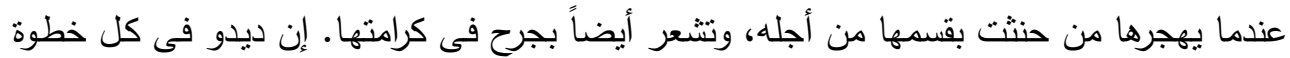

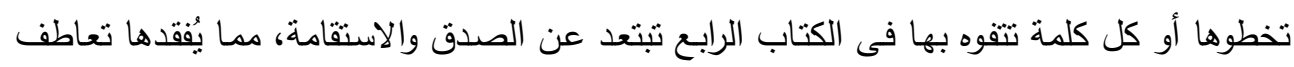
الجمهور معها. ذلك الجمهور الذى يبغى فى نفس الوقت معرفة تنطور علاقتها وافتتانها بأينياس.

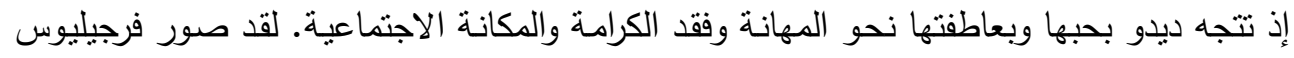
الملكة ديدو فى بداية الكتاب الرابع وهى فى حالة صدراع داخلى بين حبها وعقلها؛ كما كان حال

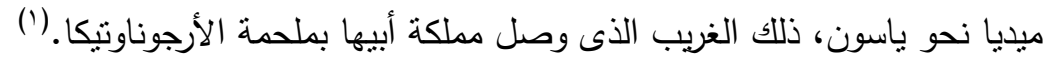
إن اللوعة والهجر والثعور بجرح الكرامة وفقد المكانة الاجتماعية الذى جاء به فرجيليوس عندما

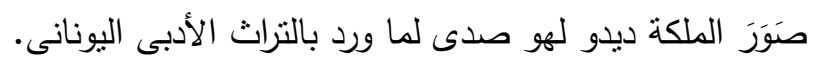

فأخيلليوس كما صوره هوميروس هو مثنال للبطل القائد القوى أمل أمته وجنوده، ولكنه عندما تُجرح كرامته فأنه يتخذ موقفاً وقراراً غير متوقعاً. إذ يقرر أخيلليوس الانسحاب من سـاحة التـال

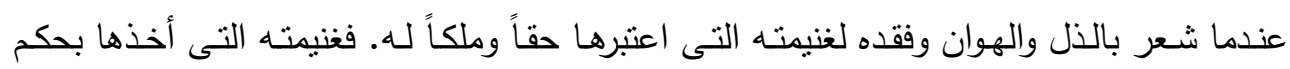

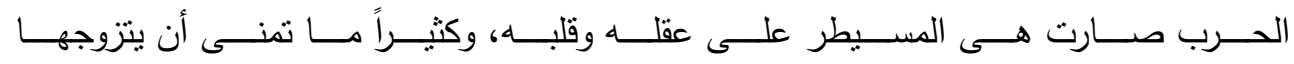

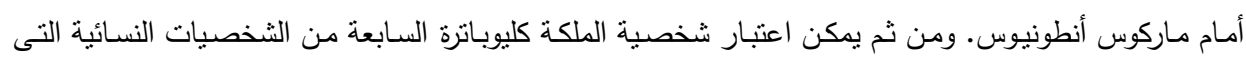

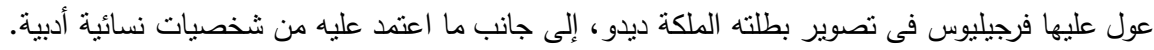
Cf., J. Higginbotham., op. cit., p. 188.

(1) J. J. Clauss and S. I. Johnstow., op. cit., pp. 170.; cf., Verg. Aen., IV, 9-29.

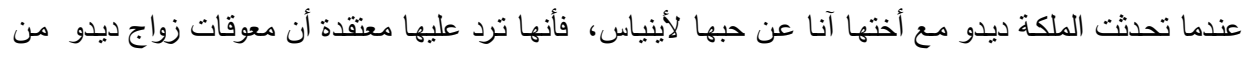

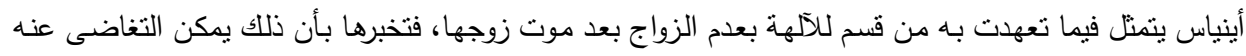
بمجرد استرضاء الآلهة وتقديم القرابين (IV, 50) (tu modo posce deos ueniam, sacrisque litatis.

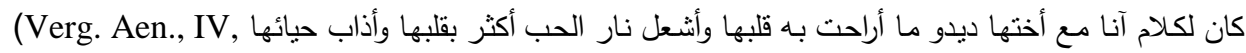

$$
\text { Cf., K.Quinn., op. cit., p. 137-138. }
$$




\section{ديدو فرجيليوس .. أصداء ملحمية وتراجيدية يونانية}

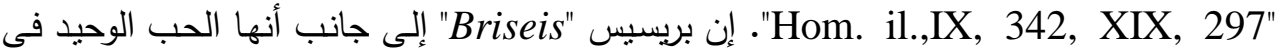

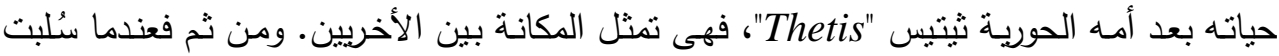

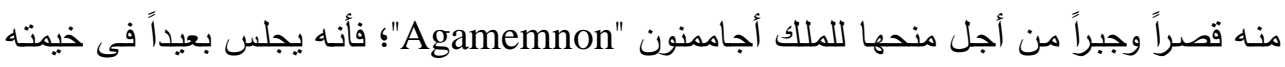

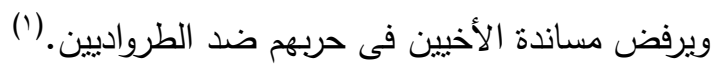

ومما ذكر عن شخصية أخيلليوس بالدوائر الهوميرية الملحمية أنه قد هام حباً بالفتاة بولوكسينا "Polyxene" إلا أنه كان على استعداد لإتمامه والزواج من ابنة عدوه، لولا أن برياموس طلب منهـه، مقابل زواجه

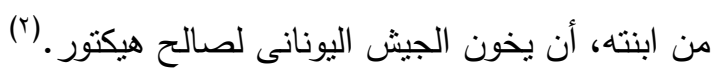

إن ما جاء عند هوميروس أو بالدوائر الملحمية الهوميرية عن أخيلليوس، سواء كانت البطولة

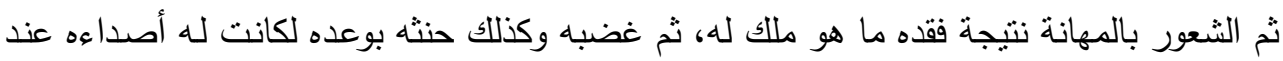

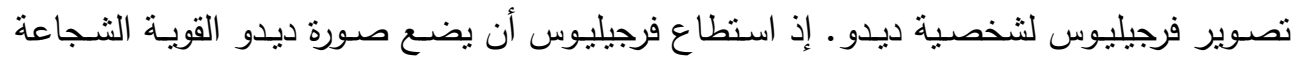

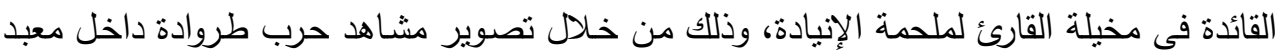

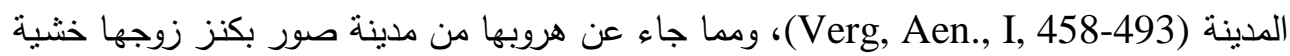

(1) Blake Tyrrell and Frieda S. Brown, Athenian Myths and Institutions, p. 55.

Cf., J. Griffin, "The Epic Cycle and The Uniqueness of Homer”, J.H.S., vol. 97, (1977), pp. 43-44.

(2) Robert Graves, The Greek Myths, Combined Editions; Penguin Books, $1^{\text {st }}$ ed. (1955), the last ed. (1992), p. 667. 163; a.

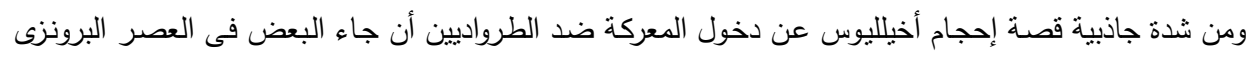

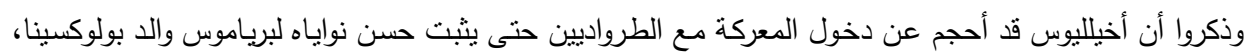

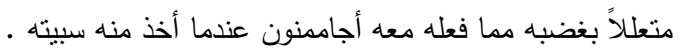

cf., Robert Graves., op. cit., P. 668. 163;b, o.; cf., H. J. Rose., Handbook of Greek Mythology, Methuen, (1953), pp. 240-241.

ويذكرنا هذا بما فعلته ديدو عندما وقعت فى حب وغرام أينياس عندما وصل إلى أرضها. فلقد كانت نشيطة فى إنى

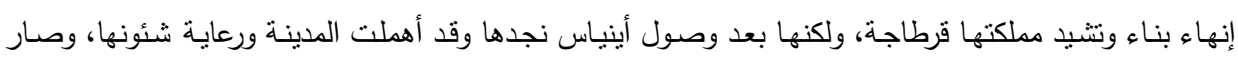

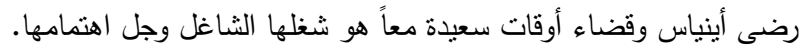


Verg. انتقام أخيها منها، ومما ذكره فرجيليوس عن قدرتها على إقامة مدينة ذات قلاع وأبراج كبيرة ( Aen., I, 360 - 368)، وقدرتها على قيادة شعب بـه رجال ذكور ومن حولها ممالك يحكمها ملوك ذكور:

imperium Dido Tyria regit urbe profecta, germanum fugiens.

(Verg. Aen., I, 340-341)

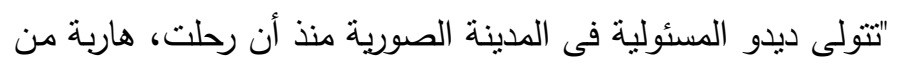

$$
\text { أخيها". }
$$

وكذللك أظهر فرجيليوس مدى قدرتها على إدارة شُئون مملكتها السياسية والتأمينية والتتريعية. إذ عندما شكى لها إليونيوس "Ilioneus"، وهو أحد رفاق أينياس، سوء معاملة أهل قرطاجة لهم فور

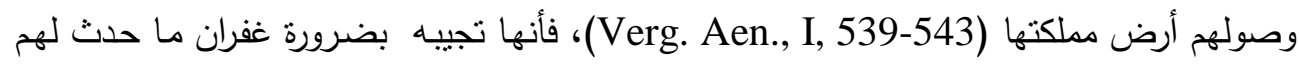

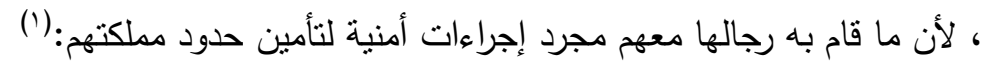
soluite corde metum, Teucri, secludite curas. res dura et regni nouitas me talia cogunt moliri et late finis custode tueri.

(Verg. Aen., I, 562-564)

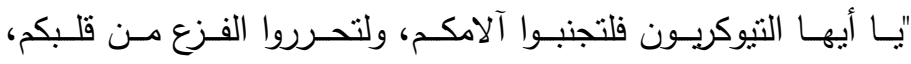

$$
\begin{aligned}
& \text { فالضرورة القاسية وحداثة المملكة تدفعانى لعمل هذه الأشياء ولمراقبة }
\end{aligned}
$$

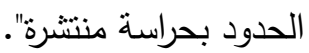

ونتيجة لما جاء عن أخيلليوس أنه قد حنث بوعده عندما أحب، نجد ديدو عند فرجيليوس هى

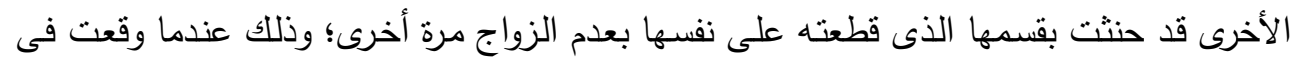

(1) K. Quinn., op. cit., p. 107. 


\section{ديدو فرجيليوس .. أصداء ملحمية وتراجيدية يونانية}

حب أينياس.(') ولكنها عندما تجرح فى كرامتها وتفقد من أحبته، فأنها تتخذ قراراً غريباً وغير منوقعاً، إذ تزمع إنهاء حياتها بالموت:

Ergo ubi concepit furias evicta dolore decreuitque mori,

(Verg. Aen., IV, 474-475)

"ومن ثم فبينما هى مغلوبة بالحزن فقد اكتنتها أرواح لغضب واتخذت

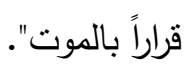

إن هذا القرار التراجيدى الذى اتخذته الملكة ديدو قد تم التمهيد له جيداً، وذلك بتكديس المشاهد والصور التى جعلت القراء على استعداد لروئة بطل نراجيدى تغير حاله ومصيره من السعادة إلى إلى

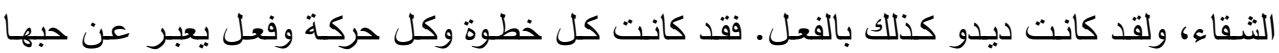
لأينياس بمثابة خطوة نحو خداع الذات والمهانة والبعد عن الحقيقة الظاهرة الواضحة للعيان. (؟) أى دئ أن مأساة ديدو كما صورها فرجيليوس ترجع فى الأساس إلى عاطفتها ورغبتها وليس إلى أينياس

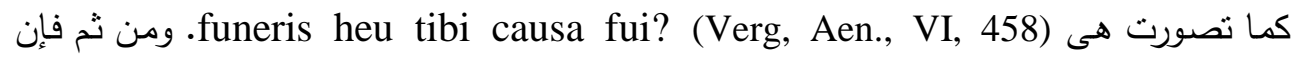
تشبيهها في بدايـة الملحمة لم يكن بغرض التشبيه أكثر منه الربط بما سوف يلى، إذ أنها صائدة

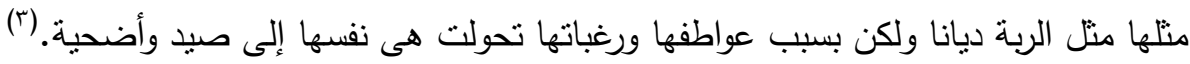

(1) فى هذا الكقام يمكن القول أن ديدو عندما أحبث أينياس فهى صدى لكل من أخيلليوس وهيراكليس. إذ أن أخيالليوس

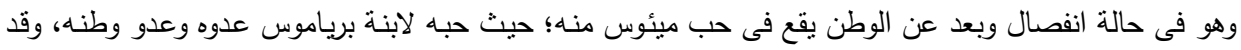

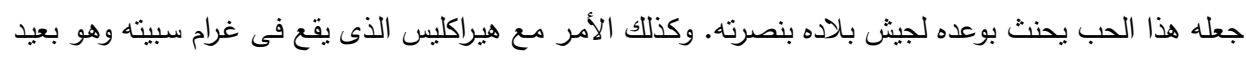
عن وطنه. فجاء فرجيليوس وفى مخيلته صورة هذا الحب الذى يصيب شخصاً وهو فى حالة انفصال عن وطنها.

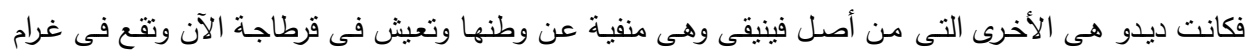
شخص منفصل هو الأخر عن وطنه.

Cf., Blake Tyrrell and Frieda S Brown, Athenian Myths and Institutions; P. 48.

(2) K. Quinn., op. cit., p. 140-145.

(3) R. A. Hornsby., op. cit., p. 339.; cf., M. C. Covi., "Dido in Vergil's Aeneid," C. J., vol, 60, (1964), pp. 58-60. 


\section{ديدو فرجيليوس .. أصداء ملحمية وتراجيدية يونانية}

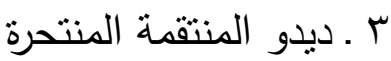

إن الثعور بالخطأ والمهانة وفقد الممتلكات هو ما يجعل ديدو تُقدم على الانتحار والموت، (')

ولقد رتبتن لهذا الانتحار ولم تأتى به فجأة ودون تقديم. إن تلك الصورة والنهاية التراجيدية المأساوية

$$
\text { لهى صدى لما جاء فى الأدب التراجيدى اليونانى. }
$$

ففى مسرحية نساء تراخيس "Trachiniae" للثـاعر التراجيدى سوفوكليس، نجد ديانيرا زوجة

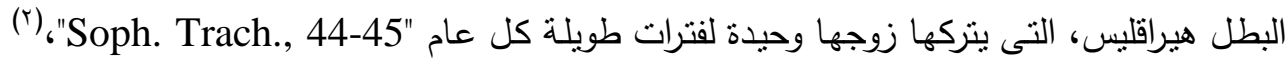

فور عِلمها بحبه لفتاة أخرى وبرغبته فيى الزواج منها؛ فأنها تحاول أن نستعيده وتجذبـه إليها مرة

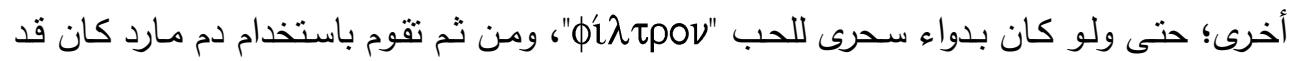

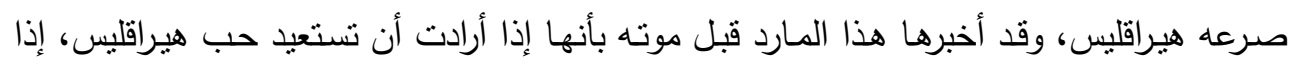
اتجهـ لغيرها، فعليها أن نستخدم هذا الدم كدواء سحرى (5oph. Trac., 555-581). ديانيرا بنفسها غرضها من استخدام هذا الدم السحرى بقولها: $\Phi^{\prime} \lambda \tau \rho \circ \iota \varsigma \delta^{\prime} \varepsilon \alpha \nu \pi \omega \varsigma \tau \eta^{\prime} \nu \delta^{\prime}$ i $\pi \varepsilon \rho \beta \alpha \lambda \omega \mu \varepsilon \theta \alpha$

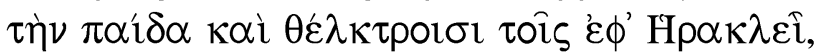

(Soph. Trac., 584-585)

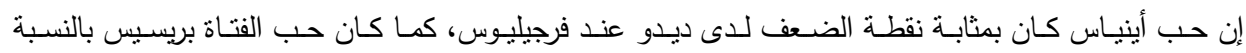

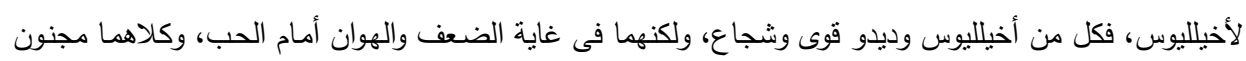

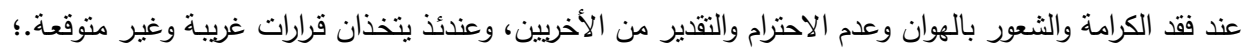
cf., J. Griffin., op. cit., p. 43-44.

(1) إذ نجدها وهى مقبلة على الانتحار تتضرع لإلهات العالم الآخر وخاصة ربة الحياء أن يغفرن لها ما فعلته، وذلك لحنثها بقسمها ووقوعها فى حب شخص الخهر أخر بعد زوجها، فحنثها هو خطأها "culpa". huic uni forsan potui succumbere culpae. (IV,19) coniugium uocat, hoc praetexit nomine culpam. (IV, 172 ).

Cf., G. E. Duckworth., op. cit., p. 359 .

(2) P. E. Easterling, The Cambridge Companion to Greek Tragedy, Cambridge University Press, (1997), p. 108. 


\section{ديدو فرجيليوس .. أصداء ملحمية وتراجيدية يونانية}

$$
\text { "عذه أية حال فإننى أبغى بهذا الدواء السحرى الحبى أن أتغلب على وأن أسحر به هيراقليس". }
$$

وعندما تدرك الخديعة التى وقعت فيها وأنها قد تتسبب فى موت زوجها هيراقليس، فأنها تتخذ

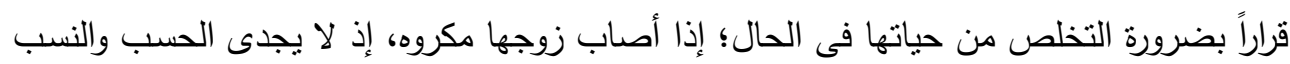

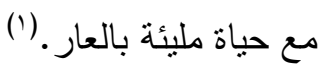

ومن ثم فعندما تعلم من ابنها هيللوس "Hyllus" ما حدث لزوجها نتيجة فعلتها، وأنـه بعد أن

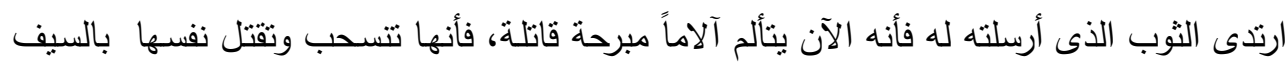
فى صدرها. (r)

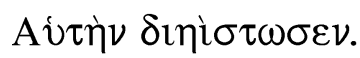

(Soph. Trch., 88)

هذه هى صورة الثنأر للذات كما رسمته التراجيديا اليونانية، حتى كانت إرثاً وتراثثاً أعاد استخدامه

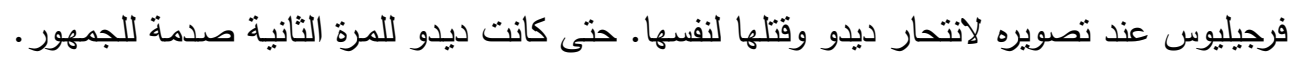

(1) Soph. Trac., 720-722 .

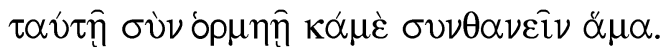

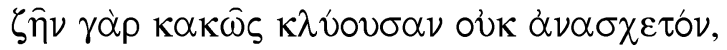

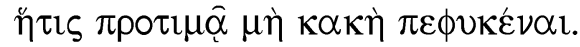

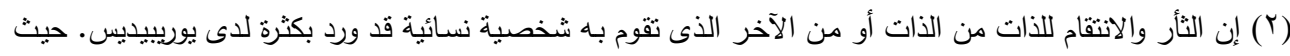

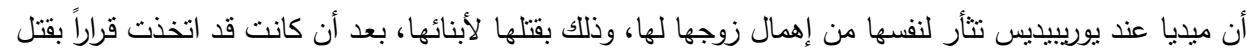

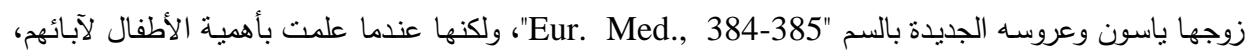

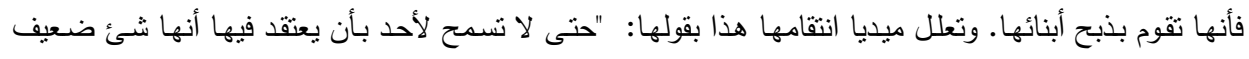

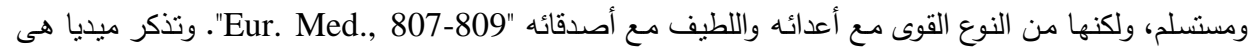

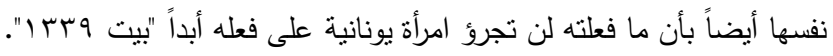

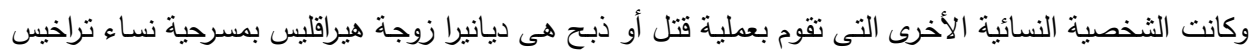

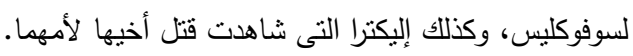

Cf., B. Tyrrell \& F. S. Brown., op. cit., pp. 117-118. 


\section{ديدو فرجيليوس .. أصداء ملحمية وتراجيدية يونانية}

فقد كانت صدمة أولى عند ظهورها كملكة حاكمة لشعبها مثل الملوك والأمراء اليونانيين والأباطرة

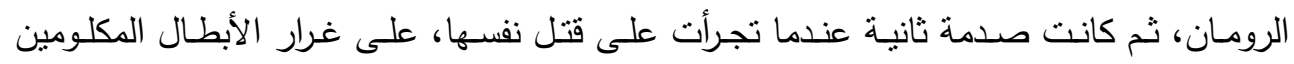

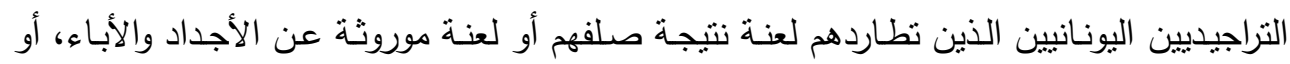
حتى نتيجة خطا ارتكبوه هم أنفسهم. (') إن أياكس ذلك البطل اليونانى والذى كان يأتى فى المرتبة الثانية فى الثجاعة بعد أخبلليوس،

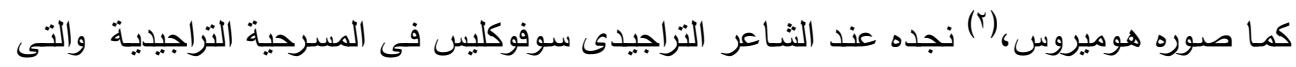
تحمل اسمه (تم عرض مسرحية أياكس فى منتصف عام •ـ؛ ؛ ق.م.) وقد شعر بالمهانـة وجرح

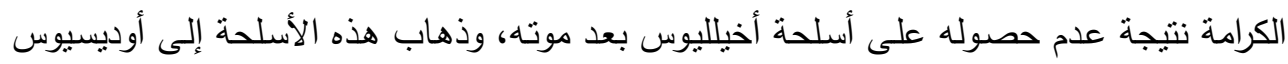
بدلا منه.(r) ونتيجة لهذا يقرر أياكس الانسحاب من ساحة القتال والانزواء فى خيمته، وفى أثناء

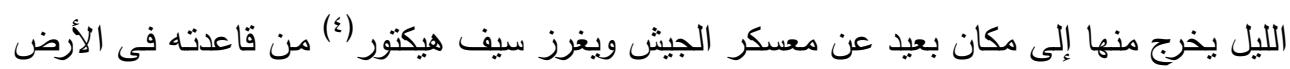

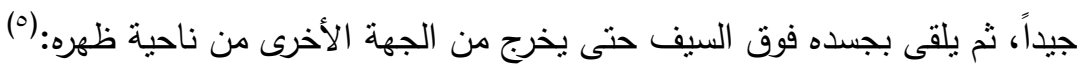

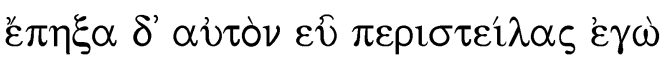

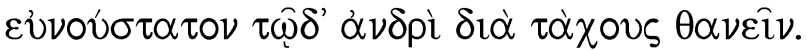

(Soph. Aiax., 821-822)

(1) فى مسرحية نساء تراخيس عندما بعلم الكورس من الوصيفة أن ديانيرا قتلت نفسها ، فأنه يسألها وكيف تجرؤ امرأة

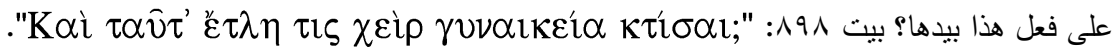

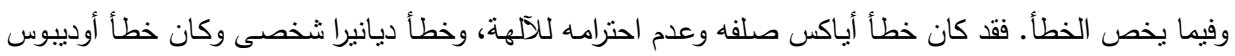
لعنة موروثة، أما خطأ ديدو فليس خطأ واضح حتى تكون نتيجته هذه النهاية المفجعة.

(2) Robert Graves, Op. Cit., P. 644. 160; b.

(3) http://en.wikipedia.org/wiki/Ajax_\%28Sophocles\%29

(§) أثناء حرب طروادة أحجم أخيلليوس عن دخول معركة فردية بينه وبين هيكتور ، وأختار اليونانيون أياكس بدلاً من

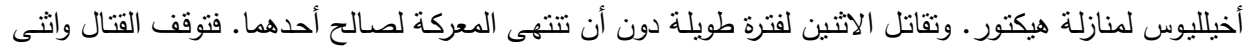

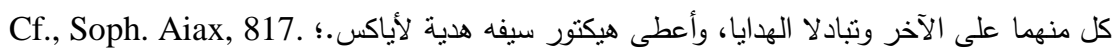

(5) Robert Graves., op. cit., p. 683; 165 passim.; cf., Hom.Od., XI, 543ff, Il., XXIII,821. 


\section{ديدو فرجيليوس .. أصداء ملحمية وتراجيدية يونانية}

$$
\text { "زرعته جيداً . السيف ـوثتنه حتى يكون معداً جيداً من أجل موت }
$$

ولم يكتف فرجيليوس بأن يكون مشهد انتحار ديدو صدى لانتحار أياكس عند سوفوكليس، ولكنه

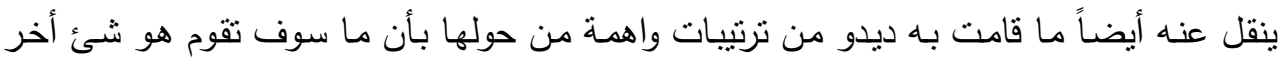
غير الانتحار،(') متل أياكس تماماً:

tempus secum ipsa modumque exigit,

(Verg. Aen., IV, 475-476)

"وأخذت تدبر بنفسها الوقت والطريقة المناسبة" .

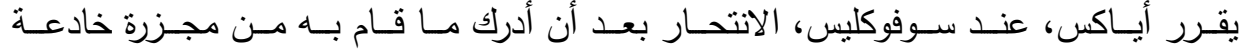

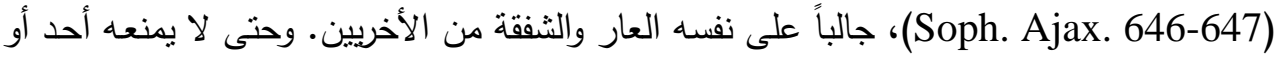

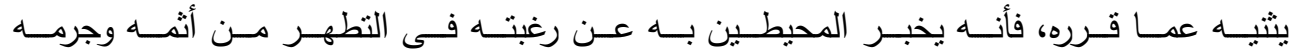

(Soph. Ajax, 648-692.) (وعندما يذهب بعيداً ويختقى عن الأنظار فأنه ينفّذ ما عقد عليه نيته

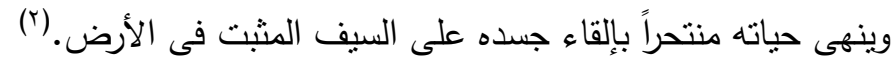

وعندما أراد فرجيليوس وقرر أن يجعل ديدو تتتحر بالسيف على طريقة أياكس سوفوكليس؛(")

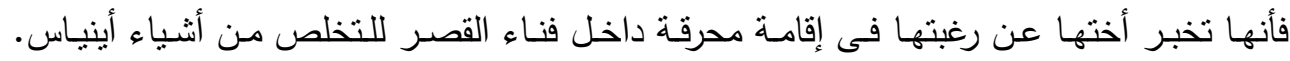

(1) K. Quinn., op. cit., pp. 333-334.

(2) Blake Tyrrell., op. cit., p. 93, 94.

(r) إن ديدو رغم ظهورها فى هذا المشهد كأنها شخصية نراجيدية، إلا أن فرجيليوس جعلها تنطق وتتفوه بكلمات ملكية،

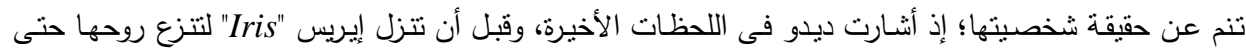
Verg. Aen., IV, 651-652, 655-) تريحها من آلامها، بأنها قد حققت إنجازات لازال على أينياس أن يحققها

Cf., K. Quinn., op. cit., p. 148, 322. 


\section{ديدو فرجيليوس .. أصداء ملحمية وتراجيدية يونانية}

وبالفعل تقيم لها أختها المحرقة، إلا أن ديدو كانت ترغب فى إحراق جثمانها على ثلك المحرقة بعد

أن تنتحر بسيف أينياس. (')

إنها صورة جديدة وغريبة لإنهاء الحياة. إذ كان يكفى أياكس أن يتبع نفس نهج أخيلليوس ويبتعد

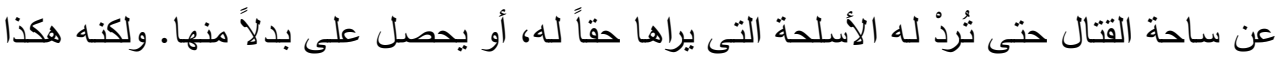

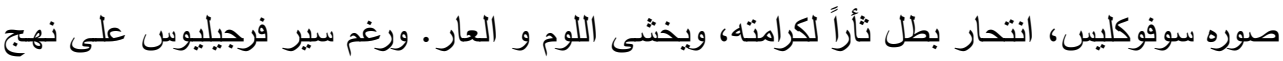

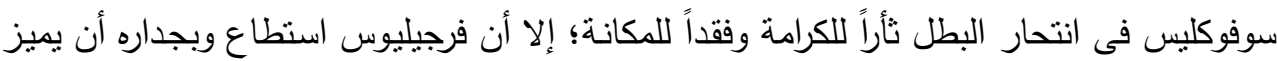

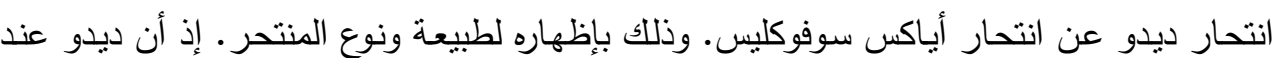
فرجيليوس امرأة، ومن ثم فقد جاء تصرفها نابعاً من كون جنسها، فانتحارها نابع عن رغبة دنه داخلية من اجل إجبار العالم على تقبل رغبتها الثخصية فى الاستحواذ على أينياس، حتى يدع قدره

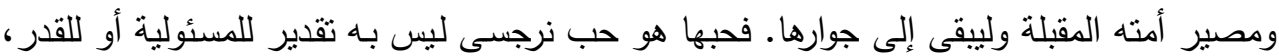
ومن ثم جعلها فرجيليوس تستتزل اللعنات على أينياس وشعبه. فهى فى لحظاتها الأخيرة مثلها مثل هئل الساحرة الضعيفة التى تدمر مالا تسنطيع أن تملكه أو تحققه.

ويزيد فرجيليوس فى تصوير اللحظات الأخيرة من حباة ديدو، بأن يجعلها لا تموت سريعاً لأنها

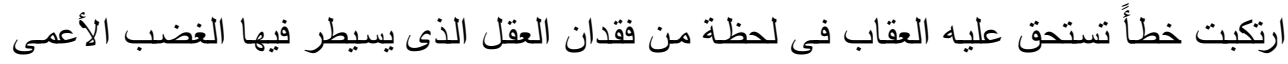

(1) إن ديدو قبل إقدامها على ما انتوت عليه من إنهاء لحياتها، نجدها وقد ظهر عليها شئ من الخوف أو الرجعة وهى (IV , فوق المحرقة at trepida et coeptis immanibus effera Dido (IV, 642 at ويرجع هذا التردد إلى أنه كان

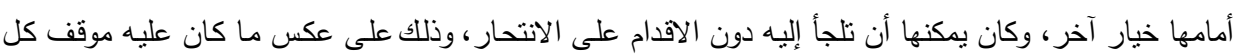

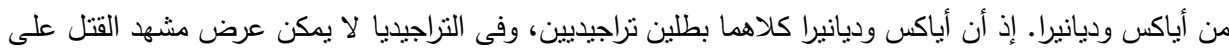
الجمهور من ناحية، ومن ناحية أخرى أن سبب الانتحار يختلف لاى ديدو عما هو لاى أياكس وديانيرا. إذ لم يكن

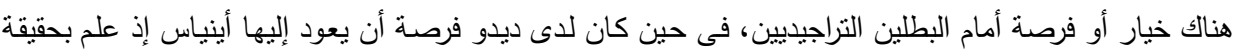

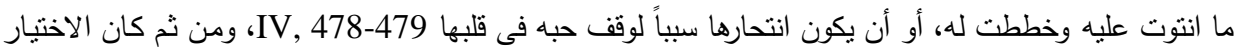
سبباً فى ترددها وخوفها من مواجهة الموت.

Cf., K. Quinn., op. cit., P. 148, 313-314, 327-329. 


\section{ديدو فرجيليوس .. أصداء ملحمية وتراجيدية يونانية}

على الإنسان، ومن ثم فهى لا تموت سريعاً كما أعدت وخططت، ولكنها تعانى سكرة الموت والتى تدرك فيها فداحة جرمها وخطورة ما أقدمت عليه ولكنها لن تعود ثانية للعالم الذى رغبت مغادرتهانه. (') ولم يكتفِ فرجيليوس بما ذكره حتى الآن عن شخصية ديدو ـ ولم يكتف بما أحدثثه من أصداء للشخصيات الملحمية والتراجيدية اليونانية التى عول عليها من أجل تجسيد شخصية ديدو؛ ولكننا

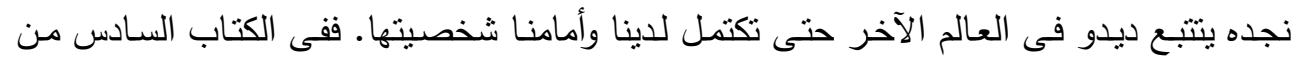

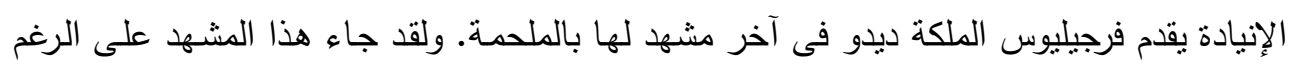

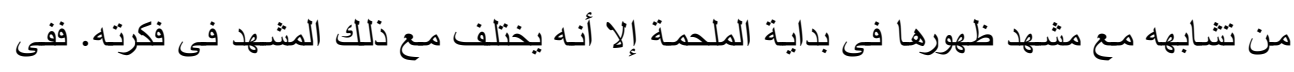

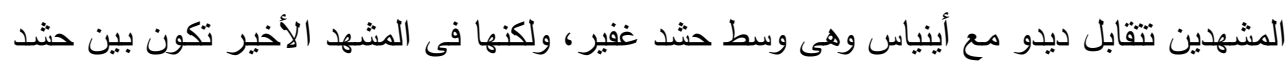

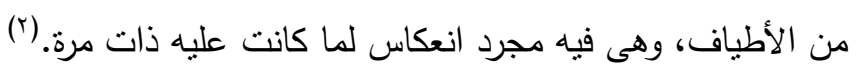
inter quas Phoenissa recens a volnere Dido errabat silva in magna. quam Troius heros ut primum iuxta stetit agnovitque per umbras obscuram,

(Verg. Aen., VI, 450-453)

(1) R. A. Hornsby, op. cit., pp. 342-343.

(2) R. A. Hornsby, op. cit., p. 343.

وتعيش هذه الأطياف فى حقول يُطلق عليها "حقول الدداد = Lugentes Campi". وسكان هذه الحقول هم من R

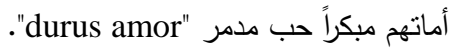




\section{ديدو فرجيليوس .. أصداء ملحمية وتراجيدية يونانية}

$$
\begin{aligned}
& \text { "وكانت ديدو الفينيقية الحديثة بين هؤلاء بجرحها تتجول فى الغابة }
\end{aligned}
$$

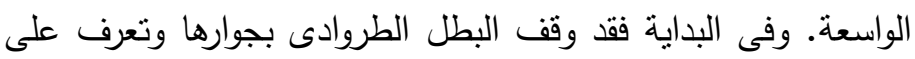

$$
\begin{aligned}
& \text { طيفها بين الأطباف .......... ". }
\end{aligned}
$$

adfare " "ويجعل فرجيليوس بطلـه أينياس يتحدث إلى طيف ديدو بحديث يفيض بالحب

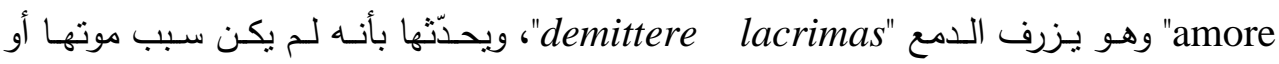
حضورها إلى هنا، ولكنها الآلهة "per superos"، إلا أنها لا تتحدث معه وتتركه وتذهب بعيداً. (( ولقد سبق وذكر فرجيليوس، بل وأكد، فى الكتاب الرابع على أن ديدو ذهبت إلى العالم الآخر

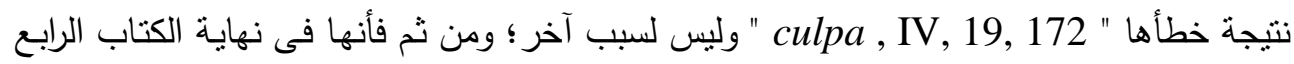
nec fato merita nec morte peribat, (Verg. Aen., IV, "كما يقول فرجيليوس قد هلكت (696"، (־) ونتيجة هذا الخطأ فقد ذهبت إلى العالم الآخر قبل وقت موتها المحدد. وكما هو واضـح أن فرجيليوس قد اهتم فى هذا المشهـ أن يوضـح السبب الحقيقى وراء كارثة

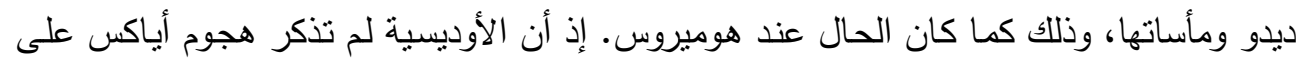
قادة الأخيين فى جنونه "550 - Hom. Od., XI, 549 - ولكنها اهتمت بذكر

(1) Verg. Aen., VI, 456-469.

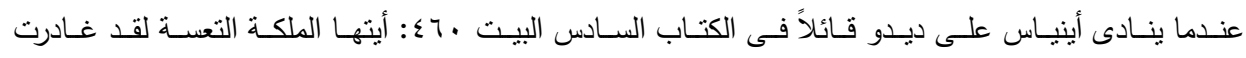
شاطئكinvitus, regina, tuo de litore cessi. إن هذا النداء بهذا الثكل وتلك المفردات النى استخدمها

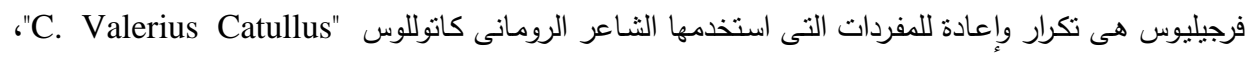

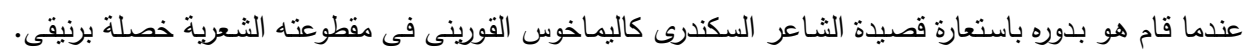

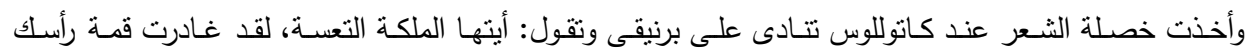
. "invita, o regina, tuo de vertice cessi"

Cf., K. Quinn, op. cit., p. 281; cf., C. R. Beye, op. cit., p. 238.

(2) G. E. Duckworth, "Fate and Free Will in Vergil's Aeneid", C.J., vol. 51, (1956), P. 359. 


\section{ديدو فرجيليوس .. أصداء ملحمية وتراجيدية يونانية}

الصراع حول أسلحة أخيلليوس بعد موته، لأن هذه الأسلحة هى سبب كارثة أياكس

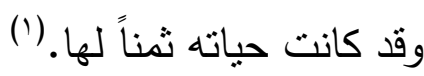

إن هوميروس فى ملحمته الأوديسية، يصور أوديسيوس وقد ذهب فى رحلة إلى إلى ألى

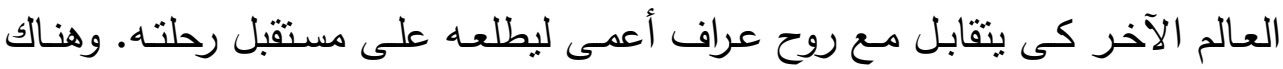

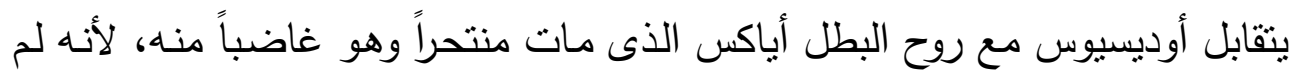

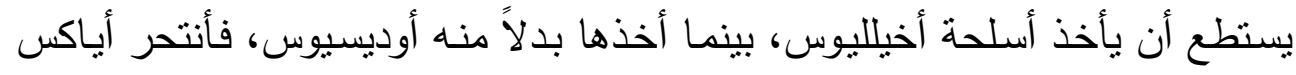

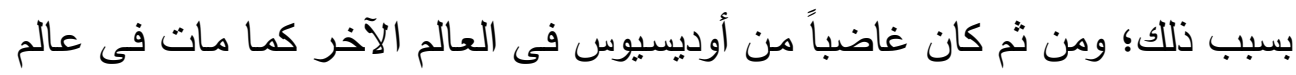

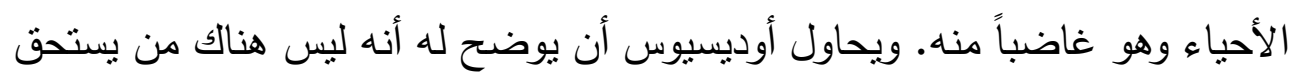

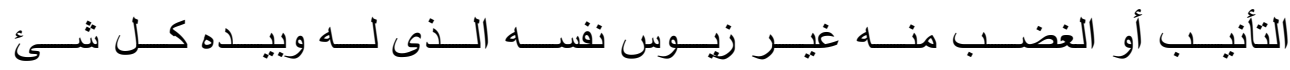

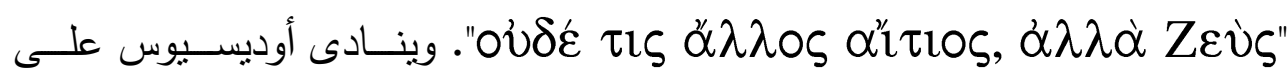
أياكس فيتركه ويذهب بعيداً عنه ولا يخاطبه.

إن ديدو فرجيليوس فى العالم الآخر لازالت غاضبة من أينياس، مثل أياكس الغاضب من أوديسيوس عند هوميروس، الذى فضنّل الرحيل عنها على البقاء بجانبها.

فعندما ذهب أينياس فى رحلة إلى العالم الآخر كى يقابل روح أبيه هناك، فأنه

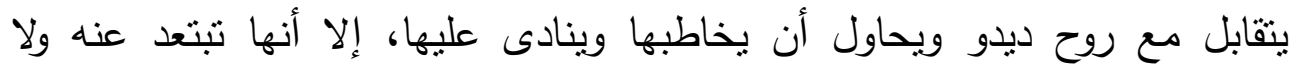

(1) جاء ذكر هجوم أياكس على قادة اليونانيين فى الإلياذة الصغرى "Ilis Parva". وكما كانت أسلحة أخيالليوس سبباً فى هلاك أياكس عند هوميروس، فقد كانت عاطفة الياكن ورغبة ديدو وحبها النرجسى سبباً فى هلاكها. Cf., J. Griffin, op. cit., p. 46.

(2) Hom, Od., XI, 543-565. 


\section{ديدو فرجيليوس .. أصداء ملحمية وتراجيدية يونانية}

تخاطبه. إذ أنه هو سبب وجودها فى هذا العالم وسبب ما أقدمت عليه. ويحاول

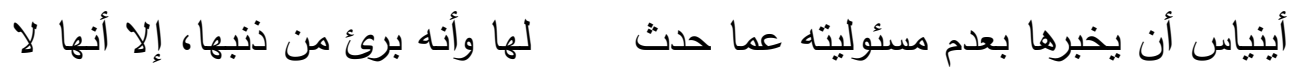

تلتفت إليه ولا إلى كلماته، وتتركه وتذهب بعيداً (Verg. Aen., VI, 472, 474) إن هذا التصوير الذى جاء به فرجيليوس عن استمرار الغضب من الأحياء حتى الغي فى العالم الآخر هو صدى لما ذكره الثاعر الملحمى هوميروس فى ملحمته

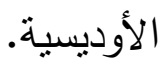

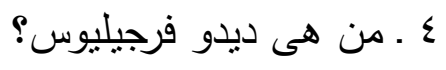

إن ما تعكسه شخصية ديدو من أصداء لثخصيات أدبية يونانية يجب أن يلفت النظر ويطرح سؤالاً ملحاً وهو، لماذا جاء فرجيليوس بهذه اهذهاء الأصداء وبذللك الوضوح

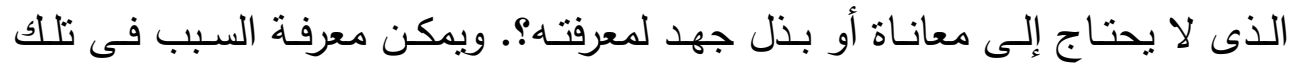
الأصداء بسهولة ويسر إذا عُرفتْ جيداً المرحلة والفترة الزمنية التى ظهر فيها الثناعر فرجيليوس.

إذ جـاء فرجيليوس فـى عصـر يبغسى السـلام والاسـتقرار والبعـد عن الصـراعات والمؤامرات. ولقد تبنى الإمبراطور أوكتافيوس أفكار وأراء سياسية واجتماعية محورها الدولة والفرد الرومانى. ولقد اعتمد الإمبراطور أوكتافيوس على مجموعة من الإدراطو الثعراء

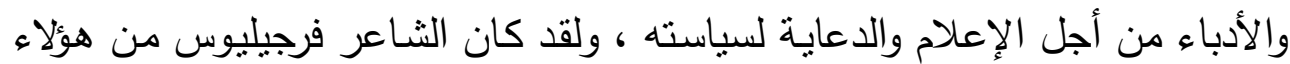
الثعراء.

ولتحقيق غرض الإمبراطور أوكتافيوس؛ قام فرجيليوس فى الإنيادة باستعراض

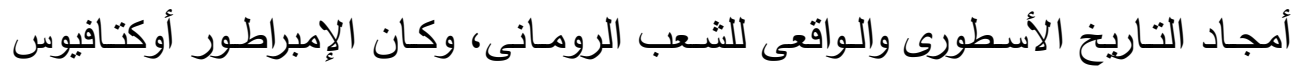

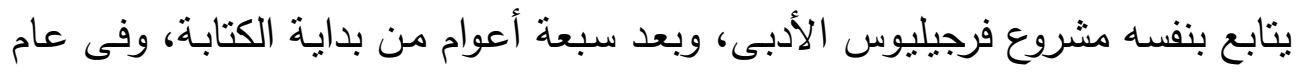




\section{ديدو فرجيليوس .. أصداء ملحمية وتراجيدية يونانية}

r T ق.م. قرأ فرجيليوس ثلاثة كتب كاملة على الإمبراطور أوكتافيوس وأخته أوكتافيا، وهم الكتب الثانى والرابع والسادس. ولهذه الكتب دلالة خاصة فى بناء ملحمة الإنيادة. إذ أن الكتاب الثانى يتحدث عن هزيمة الطرواديين على يد اليونانيين، والكتاب الرابع يتحدث عن قصة حب ديدو الجارف نحو البطل أينياس، ذلك البطل الطروادى أمل الثعب والأمة الرومانية القادمة، الذى فضّل الرحيل وترك ديدو من أجل تأسيس وطن لأمته. أما الكتاب السـادس فيتحدث عن رحلة أينياس إلى العالم الآخر ومقابلته مـع ديدو، بعد أن انتحرت لفراقه لها، واطلاعه على مستقبل أمته والثتعب الرومانى الذى إنى

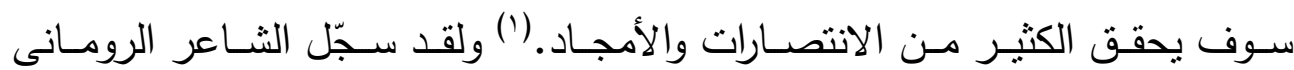
بروبيرتيوس سيكستوس "Propertius Sextus" حالة الترقب واللهفة التى يعيثـها

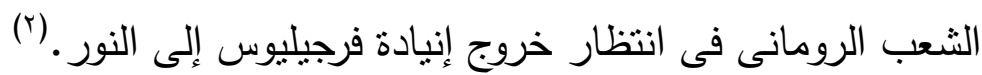
أراد فرجيليوس بتصويره لشخصية ديدو فى ملحمة الإنيادة أن يسجل قدرة الثعب

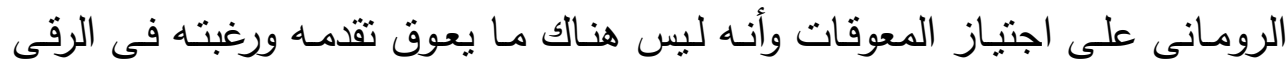
والاستقرار والسلام، وأنه لا يمكن أن تسيطر رغبة أو نزوة شخصية عليه وتبعده عن

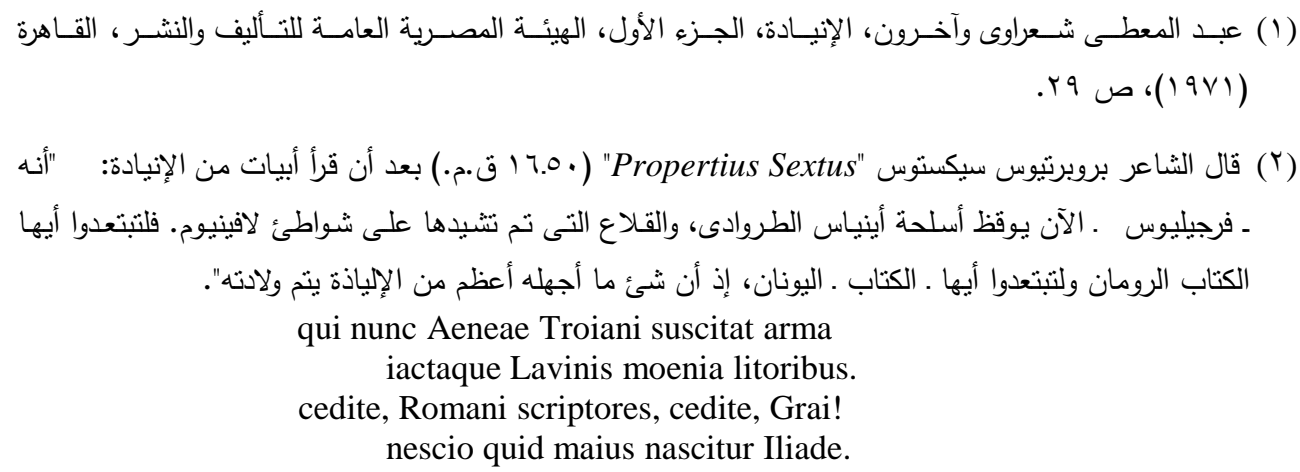
iactaque Lavinis moenia litoribus. cedite, Romani scriptores, cedite, Grai! nescio quid maius nascitur Iliade. ( Prop. II, 34, 63 - 66 ) 
هدفه، (') فالملكة ديدو هى المعوقات والحروب التى يمكن أن تعوق الاستقرار والسـام

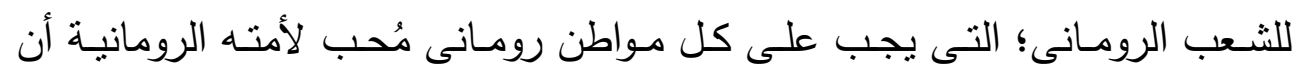
يتخلب عليها. لقد سبق كُتاب من الرومان وتحدثثا عن تناربخ الإمبراطوربة القديم وعن الحروب البونيـة، مثنل إنيـوس "Ennius" ونـايفيوس "Naevius"، إلا أن قصـة حـب الملكـة الثـرقية ديدو ولوعتهـا وهجر أينيـاس لهـا ثم انتحارهـا فهى ابتكـار ورؤيـة فرجيليـة

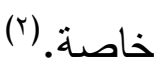

لقد ابتكر فرجيليوس شخصية الملكة ديدو وجعلها من مدينة صور الفينيقية "Dido Tyria واستطاعت أن تتشى مملكة قرطاجة "Punica regna" التى تقع على الحدود الليبية "fines Libyci" ."imperium Dido Tyria regit urbeprofecta" لقد صدم فرجيليوس جمهوره من الرومان بصورة شعب تحكمه امرأة، وهم الثعب الذكورى النزعة. وصدمهم كذللك بقدته على استدعاء شخصيات ناريخية إلى جانب الثخصيات الأدبية اليونانيـة التى استدعاها من التراث الأدبى اليونانى، ومن ثم فقد جاءت ديدو صدى لكل هذا الثخصيات الأدبية والتاريخية. لقد استطاع فرجيليوس وبجدارة أن يجعل ديدو صدى لثخصية الملكة المصرية الثرقية كليوباترة، نلك الملكة

(1) H. J. Rose, op. cit., P. 247.

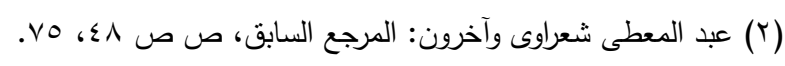


التى كانت تحكم مصر وبداخلها نزعة نحو حكم روما وشعبها الرومانى. ومن ثم فقد

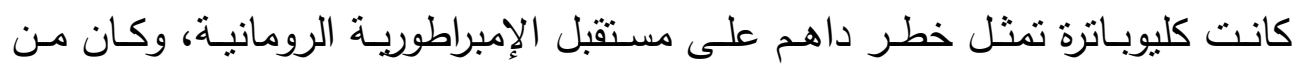

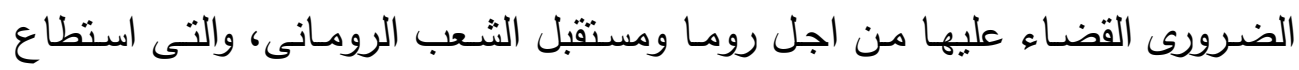

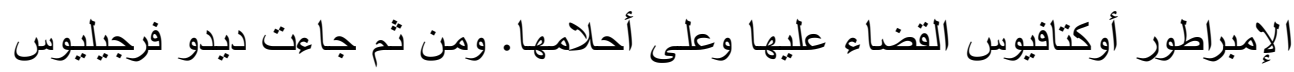
بمحاولات عدة لإعاقة أينياس عن إنشاء وطن للرومان، بإقليم لاتيوم: in Latium, sedes ubi fata quietas ostendunt; illic fas regna resurgere Troiae. (Verg. Aen., I, 205-206)

"فى لاتيوم، حيث أعدت الأقدار أماكن الراحة، فهناك سوف تنهض ثانية مملكة طروادة تبعاً للقدر".

regni " ومن تلك المحاولات أنها قد أثشركته معها فى حكم مملكتها قرطاجة demens in parte locavi (Verg. Aen., IV, 374) والمُلك الذى منحته ديدو لأينياس إلا أنه لم يتأثز بكل ذلك: sed nullis ille movetur fletibus aut voces ullas tractabilis audit;

(Verg. Aen., IV, 338-339)

"ولكنه لم يحرك فيه بكائها، أو أن يلن بما كان يسمعه من

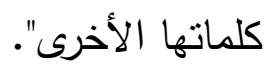

وفضّل الرحيل إلى إيطاليا من أجل توطيد وإرساء وطن للشعب الطروادى ومن أجل تحقيق مجد وسلام ذلك الثعب. 


\section{ديدو فرجيليوس .. أصداء ملحمية وتراجيدية يونانية}

لقد استدعى فرجيليوس أصداء معروفة ومعلومة من التاريخ الرومانى لتصوير ذلك الخطر المحدق بالأمسة الرومانيـة والمتمثل فى ملكة مصـر كليوبـاترة، والتى استطاع الإمبراطور التقى "Pius" أوكتافيوس بإيمانه وشجاعته أن ينتصر عليها وبحقق المجد للشعب الرومانى.

إن الملكة ديدو فى ملحمة الإنيادة تمنل قفزة حضارية ونظرة الفرد الرومانى للحكم والمُلكك، إذ قدم فرجيليوس فكرة جديدة، قد يرتضى بها البعض، حيث حكم المرأة، ولكن فرجيليوس لطبيعته ولنزعته الذكوريـة جعل هذه المـرأة تهوى بنفسـها وبثـعبها وبمن أحبته عندما أحبت ووقعت فريسة للهوى.

فتجسـيد ديـدو على هـا النحـو عند فرجيليـوس جـاء بغـرض الدعايـة والإعـلام

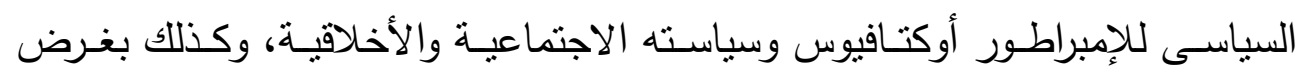
إعلاء شأن الفرد والدولة الرومانية.

إن فرجيليوس، بابتكاره لقصة ديدو على هذا النحو، يعرض على جمهوره قضية هامة ومثيرة، وهى ماذا كان يحدث لو مكث أينياس التقى الورع الأب إلى جوار ديدو بشـمال إفريقيـا؟ وأى أولويـات أهـم : المصـالح الخاصــة الفرديـة، أم المصــالح العامـة الوطنية القومية؟. 


\section{ديدو فرجيليوس .. أصداء ملحمية وتراجيدية يونانية}

\section{الخاتمــة}

إن فرجيليـوس شـاعر أغسـى يقوم بالدعايـة السياسـية والاجتماعيـة والأخلاقيـة للإدبراطـور

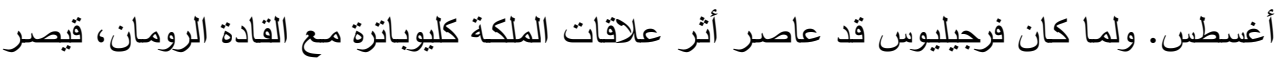

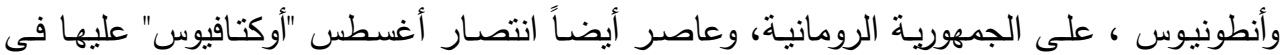

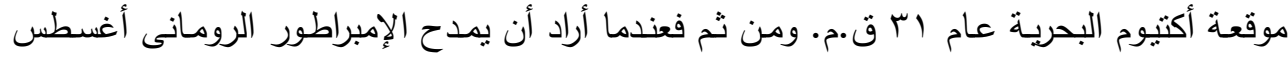

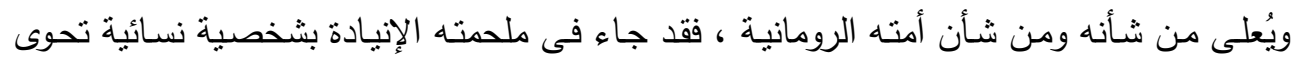
مزيجاً من السحر والرومانسية والجمال والبطولة، وجعل من هذه الثخصية ملكة ذات أصنانه أصول شرقية وتحكم شعب يقطن بشمال إفريقيا.

وجاءت الملكة ديدو عند فرجيليوس ممتلة للثرق بسحره وجماله وثراءه وقوته، ولقد وضعها فى

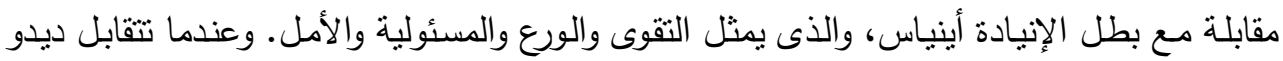

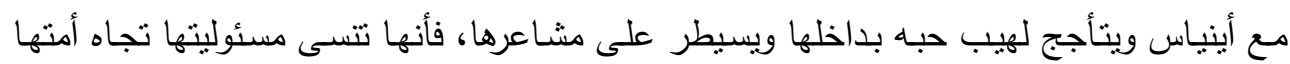

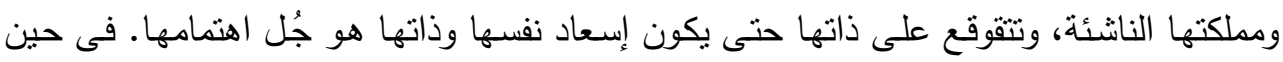
تكون الأمة ومستقبلها هى جُل اهتمام أينياس، ومن ثم بنصرف أينياس عن الملكة ديدو وحبها لله وكنوزها وعرشها الذى عرضته عليه.

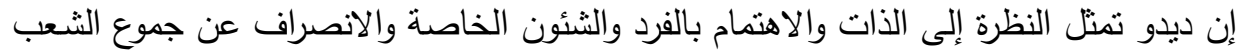

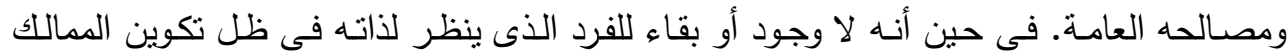

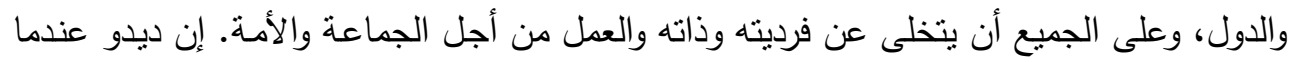

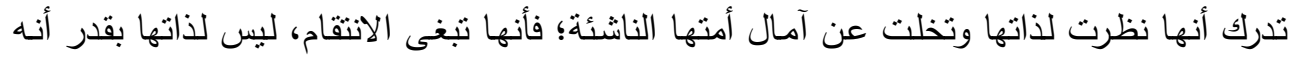
لدولتها وأمتها التى أهملت هى فى حقها، ومن ثم يتحول انتقامها نحو نفسها فتقتل ذاتها وفرديتها وأنانيتها. فى حين على الجانب الآخر كان هناك أينياس الذى يضحى براحته وسعادته وذللك من لن أجل أمته ومستقبل شعبها. 


\section{ديدو فرجيليوس .. أصداء ملحمية وتراجياية يونانية}

إن ما يمتله أينياس من صفات، التقوى والورع وإنكار الذات والثُعور بالمسئولية تجاه الجماعة

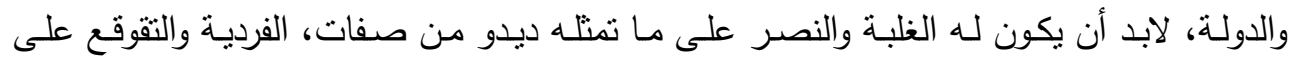
مصالح الذات والنرجسية وعدم الثعور بالمسئولية تجاه الجماعة والدولة. 


\section{ديدو فرجيليوس .. أصداء ملحمية وتراجيدية يونانية}

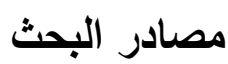

- Fairclough H. R., Virgil, With an English Translation, Loeb Classical Library, (1932).

- Monro D. B. et Allen T. W., Homeri Opera, "Odyssea” I, II; Scriptorum Classicorum Bibliotheca Oxoniensis.

- Murray A. T., Homer, The Odyssey, With an English Translation, Loeb Classical Library, $7^{\text {th }}$ ed. (1946).

- Seaton R. C., Apollonius Rhodius, The Argonautica, With an English Translation, Loeb Classical Library, $5^{\text {th }}$ ed. (1955).

- Storr F. "B. A.”, Sophocles; II Ajax \& Trachiniae, With an English Translation, Loeb Classical Library .

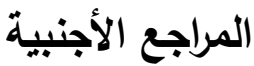

- Anderson W. S., “Calypso and Elysium”, C.J., vol. 54, (1958), pp. 2-11.

- Beye C. R., Ancient Epic Poetry, Homer, Apollonius and Virgil; Cornel University Press, Ithaca and London, (1993).

- Blake Tyrrell and Frieda S. Brown, Athenian Myths and Institutions .

- Clauss J. J., "Domestici Hostes: The Nausicaa in Medea, The Cataline in Hannibal”, Materiali e Discussioni per L'Analisi dei testi Classici; vol. 39, (1997), Piza, Rom. pp. 165-185 .

- Clauss J. J. and Johnstow S. I., Medea, Essays on Medea in Myth, Literature, Philosophy and Art, Princetm University Press, (1997).

- Covi M. C., "Dido in Vergil's Aeneid,” C.J., vol, 60, (1964), pp. 57- 60.

- Donaldson J., Women: Her Position and Influence in Ancient Greece and Rome and Among Early Christians, press New York, (1973).

- Duckworth G. E., "Fate and Free Will in Vergil's Aeneid", C. J., vol. 51, (1956), p. 357-364. 


\section{ديدو فرجيليوس .. أصداء ملحمية وتراجيدية يونانية}

- Easterling P. E., The Cambridge Companion to Greek Tragedy, Cambridge University Press, (1997).

- Edwards M. J., "Scenes From The Later Wanderings of Odysseus", C.Q., vol, 38 II, (1988), pp. 509-521.

- Gransden K. W., Virgil, The Aeneid, N.Y., 1990 .

- Griffin J., "The Epic Cycle and The Uniqueness of Homer", J.H.S., vol. 97, (1977), pp. 39-53 .

- Graves R., The Greek Myths, Combined Editions; Penguin Books, $1^{\text {st }}$ ed. (1955), The last ed. (1992).

- Higginbotham J., Greek and Latin Literature; A comparative Study, London, (1969).

- Holtsmark E. B., "Spiritual Rebirth of The Hero: Odyssey 5", C.J., vol. 61, (1966), P. 206- 210.

- Hornsby R. A., "The Vergilian Simile as Means of Judgment", C.J., vol., 60, (1965), pp. 337-344.

- Quinn K., Virgil's Aeneid, A critical description, Toronto, Routledge \& Kegan Paul Press, $1^{\text {st }}$. ed. (1969), the last ed. (1978).

- Rose H. J., A Handbook of Latin Literature, From The Earliest Times to The Death of St. Augustine; University Paperbacks, Methuem \& Co LTD: London, (1967).

- Rutherford R. B., "The Philosophy of The Odyssey", J.H.S., vol. 106, (1986), pp. 145- 162.

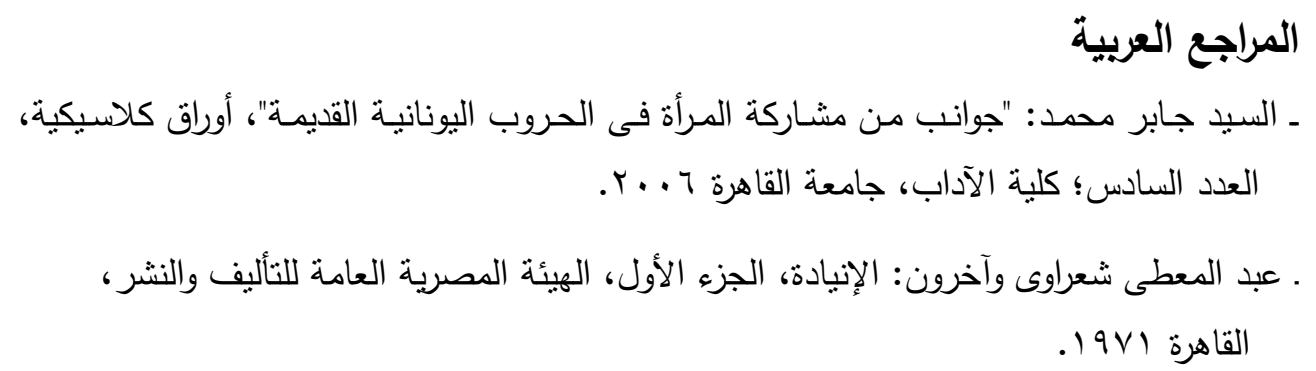

